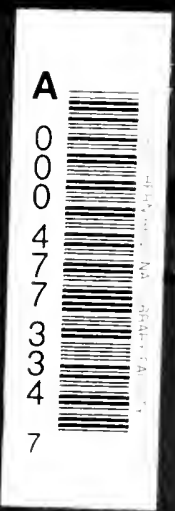

$$
\begin{aligned}
& \text { IDINAVIAN RELA. } \\
& \text { S WTPH IRELANI } \\
& \text { MG DHE VIISHC } \\
& \text { PERTOD }
\end{aligned}
$$

nia 

ULSE LIBRARY

$$
X-22478
$$


Digitized by the Internet Archive in 2007 with funding from

Microsoft Corporation 


\section{SCANDINAVIAN RELATIONS WITH IRELAND DURING THE VIKING PERIOD}





\title{
SCANDINAVIAN RELATIONS WITH IRELAND DURING THE VIKING PERIOD
}

\author{
BI \\ A. WALSH
}

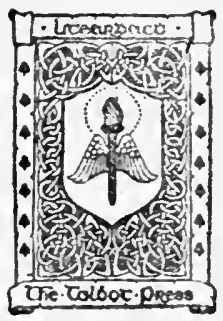

\section{DUBLIN \\ THE TALBOT PRESS LIMITED \\ LONDON}

T. FISHER UNWIN LIMITED

1922 



\section{PREFACE}

This short study was written during my tenure of a Travelling Studentship from the National University of Ireland, and in March, I920, was accepted for the Research Degree Certificate of Cambridge University.

A glance at the bibliography shows that comparatively little has been written in English on this interesting period of our history. On the other hand modern Scandinavian scholars-Alexander Bugge, Marstrander, and Vogt-have thrown a good deal of light on the subject, but unfortunately very few of their books have been translated into English. The present dissertation is based principally upon the Old and Middle Irish annals and chronicles and the Icelandic sagas; reference has also been made to the work of Scandinavian, English and Irish scholars on the subject.

I should like to acknowledge my debt to Professor Chadwick, who directed my work : those who have had the privilege of working under him will readily understand how much is due to his encouragement and stimulating criticism. I wish also to express my thanks to my friends, Miss N. Kershaw and Mr. E. J. Thomas, for many kindnesses while the book was in preparation; to Miss Eleanor Hull and Professor O'Máille, University College, Galway, for the loan of books ; and to the Librarian and staff of Cambridge University Library, the National Library, Dublin, and T.C.D. Library. 



\section{CON'TEN'TS}

PAGE

PREFACE

Chap.

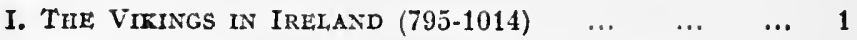

II. INTERCOURSE BETWEEN THE GAILL AND THL GAEDHIL

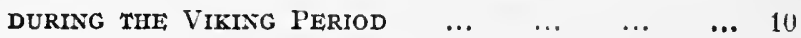

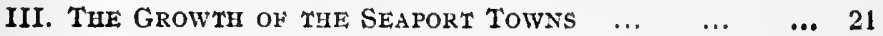

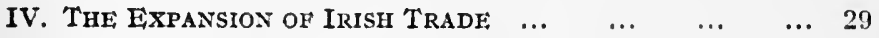

V. Shipbuilding aNd Seafaring $\quad \ldots \quad$.

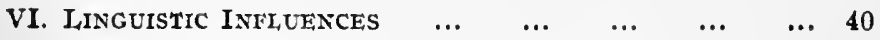

(a) Loan-words from Old Norse in Irish.

(b) Gaelic Words in Old Norse Literature.

(c) Irish Influence on Icelandic Place-nomenclature.

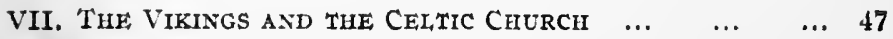

VIII. LITERARY INFLUEACE. THE SAGAS OF ICELAND AND

$\begin{array}{lllllllll}\text { IRELAND } & \ldots & \ldots & \ldots & \ldots & \ldots & \ldots & \ldots & 57\end{array}$

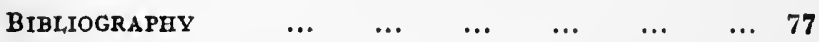





\section{Scandinavian Relations with Ireland during the Viking Period.}

\section{CHAPTER I. \\ THE VIKINGS IN IRELAND (795-IOI4).}

TrE Vikings made their first appearance ${ }^{1}$ on the Irish coasts in 795 A.D., when they plundered and burned the church on Recru, or Lambay Island, near Dublin. During the next ten or twelve years Ireland seems to have been almost free from further attacks, but in 807 they descended on Inis Murray, off the Sligo coast, and from there made their way inland to Roscommon.2 After that the raids ceased for a few years, then began again with renewed vigour on Connacht and Munster, on some of the inland counties of Ieinster, and on several places along the east coast. ${ }^{8}$

The arrival of Turgeis (O.N. Thorgestr) in Armagh, about 832, marks a new phase of the invasions. Hitherto the Vikings had come in isolated parties solely for purposes

1 Zimmer was of the opinion that the Norsemen made their way to Ireland as early as the seventh century. He bases lis theory on an entry in the Annals of Ulster and in certain other Irish annals (under the year 617 ) recording "the devastation of Tory Island by a marine fleet.": (über die frïhesten Berührungen der Iren mit den Nordgermanen, p. $279 \mathrm{ff}$. in Sitzungsbevichte der kgl. preussischen Akademie der Wissenschaften. I89r. Bd. I., pp. 279-317.) But this attack is likely to have been due to Saxon or Pictish raiders rather than to the Norsemen.

Annals of the Four Masters, A.D. 807.

Annals of Ulster, A.D. 8Ir, 820-824, 827, 830 .

- Some writers would identify Turgeis with Thorgils, son of Harold Fairhair, who with his brother Frothi went on a viking expedition to Ireland. They captured Dublin, and Thorgils reigned there for a long time as king. In the end, however, he was betrayed by the 
of plunder; nor, however, "great sea-cast floods of foreigners" landed in every harbour, and began to form settlements in various parts of the island. Dublin was first occupied in 836, and four years later the Norsemen strengthened their position there considerably by the erection of a longphort or fortress. From their longphort at Linn Duachaill (between Drogheda and Dundalk) built in the same year, they made their way to the West and plundered Clonmacnois, while settlers from Cael-uisce, near Newry, went south and laid waste County Kildare. ${ }^{1}$

The power of Turgeis was not confined to the north of Ireland. His fleets were stationed on Loch Ree, the centre from which. Meath and Connacht were devastated. His wife, Ota (O.N. Authr), desecrated the monastery of Clonmacnois by giving her oracular responses (a frecartha) from the high altar. ${ }^{2}$ The tyranny of Turgeis came to an end in 845 , when he was captured by Maelsechnaill, who afterwards became $\boldsymbol{d} \boldsymbol{r} \boldsymbol{d}$ - $\boldsymbol{r} \boldsymbol{t}$, and was drowned in Lough Owel."

After his death the tide of battle turned in favour of the Irish, and the Norsemen were defeated in several battles. Weakened by warfare, they had to contend in 849 with an enemy from without-the Dubh-Gaill' or Danes who had

Irish and was killed. (Heimskringla: Haralds saga hins hárfagra, ch. 35.)

This account of Thorgils certainly bears a resemblance to that of Turgeis contained in the Irish chronicles and Giraldus Cambrensis (cf. Todd: Introduction to War of the Gaedhil with the Gaill, I., ii.), but it is of course incorrect to say that Turgeis was a son of Harold Fairhair.

${ }^{1}$ Annals of Ulster, A.D. 84r.

${ }^{2}$ War of the Gaedhil with the Gaill, p. I3.

${ }^{3}$ Ib., p. 15.

- The Irish chron'clers use a variety of names for the Scandinarians : Dibearccai (outlaws), Gaill (foreigners), Gennti (Gentiles), and Pagánaigh (Pagans). They also distinguish between Danes and Norsemen. The Danes were known as Danair, Danmarcaigh, Dubh 
sailed round the south coast of England and landed in Ireland "to exercise authority over the foreigners who were there before them." Two years after their arrival the newcomers plundered the fortresses at Dublin and Dundalk, but were attacked in the following year on Carlingford Loch by the Norsemen. In this great naval battle, which lasted three days and three nights, the Danes were finally victorious. ${ }^{1}$

"Amhlaoibh Conung, son of the King of Lochlann," known in Icelandic sources as Olaf the White, came to Ireland about 852 to rule over his countrymen, and to exact tribute from the Irish. ${ }^{2}$ According to the Fragments of Annals, he left suddenly and returned a few years later accompanied by his "younger brother, Imhar," Who may be identified with fvarr Beinlausi (i.e., "the Boneless") son of Ragnarr Lothbrók. Both kings ruled from Dublin, which town now gained a new importance as the seat of the Scandinavian Kings in Ireland. In 865 the Vikings extended their activities to Scotland, whence they carried off much plunder and many captives. An expedition on a larger scale was made by Olaf and Ivarr in 869 , when Dumbarton, after a four months' siege, fell into their hands. They returned in triumph to Ireland in the following year with a large number of English, British, and Pictish prisoners

Gennti (Black Gentiles), and Dubh-Gaill. The word Dubh-Gaill (Black Foreigners) still survives in the personal names Doyle and MacDowell and in the place-name Baldoyle. The Norsemen were called Finn-Gaill (Fair Foreigners), Finn-Genti, Nortmannai (Lat. Northmanni) and Lochlannaigh (i.e., men of Lochlann or Norway).

1 Annals of Ulster, A.D. $85 \mathrm{I}(=852)$.

${ }^{2}$ Three Fragments of Annals, p. 127.

Vogt (Dublin som Norsk By, p. 66) suggests that Olaf was related to Turgeis, the first Norse King of Ireland, and to Earl Tomrair (O.N. Thórarr), "tanist of the King of Lochlann," who fell in the battle of Scaith Neachtain $(847)$. On the other hand it may be noted here that the Annalist errs in making Olaf a brother of Ivarr the Boneless. 
and ended their victorious march by the capture of Dunseverick (Co. Antrim). ${ }^{1}$

Olaf returned to Norway some time after this to take part in the wars there, and we hear no more of him in the Irish Annals. "Imhar, King of the Norsemen of all Ireland and Britain," did not long survive him ; his death is recorded under the year $873 .^{3}$

During the years which followed Ivarr's death the country was comparatively peaceful, and the Irish began to enjoy a rest from fresh invasions, which lasted about forty years." The Danes and the Norsemen again began to quarrel among themselves, and once more their opposing fleets met on Carlingford Lough $;^{5}$ in this battle Albann (O.N. Halfdanr), brother of Ivarr, a well-known leader of the Vikings in England, was slain. Dissensions also spread among the ranks of the Dublin Norsemen, dividing them into two hostile parties, one siding with Sitriucc, son of Ivarr, the other with a certain Sighfrith. ${ }^{\circ}$ This internal strife so

1 Annals of Ulster, A.D. 870.

${ }^{2}$ Three Fragments of Annals, p. 195. The Landnámabók, II., ch. I5 says that "Olaf fell in battle in Ireland," but this is surely a mistake.

3 Annals of Ulster, sub anno, $872(=873)$.

- Cf. War of the Gaedhil with the Gaill, p. 27. Cf. also the entries in the Annals of Ulster:

"Ruaidhri, son of Muirmenn King of the Britons came to Ireland, fleeing before the Black Forcigners" (an. 876).

"The shrine of Colum-Cille and all his relics were brought to Ireland to escape the Foreigners" (an. 877).

- The War of the Gaedhil with the Gaill (p. 27) mentions another battle between Fair and Black Gentiles, in which many of the latter were killed.

- It is extremely difficult to identify these two princes owing to the similarity between their names. It has been suggested that Sighfrith is the Siefredus or Sievert who ruled jointly with Guthred. Cnut (d.c. 894) as King of Northumbria, while Sitriucc son of Ivarr is probably the "Sitric comes" whose name appears on a coin dating from this period. (See A. Mawer: The Scandinavian Kingdom of Northumbria, pp. II-13. Saga-book of the Viking Club, VII. Part I.) 
weakened Norse power that the Irish captured the fortress at Dublin in 902, and drove the Vikings across the sea with great slaughter.

The forty years' rest terminated abruptly in 913 , when several fleets arrived at Waterford and proceeded to ravage all Munster and Leinster. In 9I6 Raghnall (O.N. Rögnvaldr), grandson of Ivarr, assumed command while his brother or cousin, Sihtric Gale (also nicknamed Caoch, ' the Blind ') came with a fleet to Cenn Fuaid, in the east of Leinster, and built a fortification there. ${ }^{1}$ Both chiefs united forces against the $d r d-r i$ Niall Glundubh, and having defeated him in battle Sihtric entered Dublin and became king (9r8). In the following year the Irish under Niall made a brave stand at Kilmashogue, near Dublin, but Sihtric won a decisive victory, and Niall and twelve other kings were among the slain. ${ }^{2}$

Scandinavian power in Ireland was now at its height. Large fleets occupied all the lakes in Ulster, so that no part of the surrounding territory was safe from their attacks. ${ }^{8}$ The Vikings also retained their grip of the coast towns, and successfully withstood the efforts made by the Irish leaders to dislodge them. Between the years 920 and 950 the importance of Dublin increased considerably through its connection with the Scandinavian Kingdom of Northumbria. Raghnall, grandson of Ivarr, captured York about $919^{4}$ and reigned there until his death in $92 \mathrm{I}^{5} \mathrm{He}$ was succeeded

1 Annals of Ulster, A.D. $9 \mathrm{r} 6$.

2 Annals of Ulster, A.D. 9r8. War of the Gaedhil with the Gaill, p. 37. An entry in the Anglo-Saxon Chronicle (A.D. 921), referring to the result of this battle, runs :- "In this year King Sihtric slew his brother Niel." There is, however, no evidence in Irish sources that Sihtric and Niall were brothers, or even half-brothers.

s Annals of Ulster, A.D. 920, 921, 923, 925.

- Anglo-Saxon Chronicle, A.D. 923.

B Annals of Ulster, A.D. 920. 
by Sihtric Gale, who had been expelled from Dublin in the preceding year, ${ }^{1}$ probably by his brother, Guthfrith. After Sihtric's death in 927 Guthfrith, King of Dublin (d. 934), with the Vikings of Dundalk, left Ireland in order to secure his own succession in York, but he would seem to have been driven out by Aethelstan, for the Irish Annals mention his return to Dublin after an absence of six months.?

Guthfrith's son, Olaf, came forward about this time. Supported by the Norsemen of Strangford Lough he plundered Armagh, but his subsequent attacks on Ulster were checked by Muirchertach MacNeill, son of Niall Glundubh. Olaf fought in alliance with Constantine in the battle of Brunanburh (937), and after the defeat inflicted on them by Aethelstan's forces he fled to Dublin." He is probably the "Anlaf of Ireland" who was chosen King by the Northumbrians in $94 \mathrm{I}$, but he died about a year later. ${ }^{\mathrm{s}}$

Another Olaf, the famous Olaf Cuaran, also called Sihtricsson to distinguish between them, also played an important part in campaigns in Ireland and England. He went to York about 94I, and was elected king by the Northumbrians, but was expelled after a few years along with Raegenald, son of Guthfrith. ${ }^{\circ}$ He then took the Dublin Kingdom under his rule, and in the following year was defeated in battle by the Irish at Slaine (Co. Meath). Leaving his brother Guthfrith to govern in his stead, he departed to York, where he became king a second time; but the Northumbrians drove him out after three years and placed

1 Annals of Ulsier, A.D. 919.

Ib., A.D. 927.

3 Ib., A.D. 937. Anglo-Saxon Chronicle. A. Annal, 937.

- Anglo-Saxon Chronicle, D. Annal $94 \mathrm{I}$.

Ib., E. Annal 942 ; Annals of Clonmacnoise, A.D. 934.

- Anglo-Saxon Chronicle, A. Annal 944. 
"Yric, son of Harald" (i.e., Eric Bloodase, late King of Norway) on the throne."

Henceforward Olaf limited his activities to Ireland, where he reigned, the most famous of the Dublin Kings, for some thirty years. In 980, having summoned anxiliaries from the Scottish isles and Man, he prepared to attack the $d r d-r i$, Maelsechnaill II. A fierce battle was fought between them at Tara in which the Norse armies were completely routed, Olaf's son Raghnall being among the slain. Maelsechnaill followed up this victory by a three days' siege of Dublin, after which be carried off a number of hostages from the Norsemen, and also obtained from them 2,000 kine, together with jewels and various other treasures. ${ }^{2}$ Olaf himself, utterly disheartened by his defeat, went on pilgrimage to Iona, where he died soon after.

Some fifteen years before, a severe blow had been struck at the power of the Limerick Vikings under Ivarr, grandson of Ivarr and his sons. The attack made on them at Sulcoit (968) by two princes of the Dal Cais, the brothers Mathgamain and Brian, resulted in victory for the Irish, who took Limerick shortly after. ${ }^{3}$ Mathgamain was treacherously murdered in 976 , and Brian then became King of Thomond. He soon brought the Kingdoms of Ossory and Leinster under his control, and by the terms of a treaty made in 998 Maelsechnaill consented to leave Brian master of Leth Mogha (i.e., the southern half of Ireland). The Leinstermen under King Maelmordha, dissatisfied with this arrangement, began to make trouble and revolted, assisted by the Dublin Norsemen. An important victory was gained over their combined armies at

1 Anglo-Saxon Chronicle, E. Annals 949, 952.

Annals of the Four Masters, A.D. 978, 979; Annals of Ulster, A.D. $979(=980)$.

${ }^{8}$ War of the Gaedhil with the Gaill, p. 77. 
Gleann Mama (Co. Wicklow) in the year rooo by Brian, who after the battle captured Dublin. King Sihtric (O.N. Sigtryggr), son of Olaf Cuaran, had to submit to Brian's authority. Having accepted his allegiance Brian married Gormflaith, mother of Sihtric and sister of Maelmordha, and at the same time gave his own daughter to Sihtric in marriage. ${ }^{1}$

Brian became ard-ri in I002, and after that for about twelve years there was peace. Towards the end of that time Gormflaith, who had meanwhile separated from her husband, incited her brother Maelmordha to make war on Brian. Maelmordha and Sihtric began to gather forces for the coming struggle. Sihtric at his mother's command sought the aid of Sigurthr, Earl of Orkney and of Brodar, a Viking whose fleet then lay off the west coast of Man. Fleets also came from Norway ${ }^{3}$ and Iceland to help their kinsmen. The armies under Brian and Maelsechnaill marched towards Dublin, and having encamped near Kilmainham set fire to the district of Fingal (i.e., Fine Gall, "the Foreigners' territory") north of the city. The two armies met at Clontarf on Good Friday morning and the battle, one of the most famous ever fought on Irish soil, raged all that day. The Norsemen suffered a severe defeat, and in attempting to fly for refuge to their ships were slaughtered by Maelsechnaill at Dubhgall's Bridge, near the Four Courts. Brian himself did not take part in the fight, but he was slain in his tent by Brodar after the battle."

${ }^{1}$ War of the Gaedhil with the Gaill. p. II5; Annals of the Four Masters, A.D. 997.

${ }^{2}$ War of the Gaedhil with the Gaill, p. 153. Njails Saga, ch. 155. In the Annals of Loch Ce (A.D. Ior 4) Brodar is called the earl of York (iarla Caoire Eabhroigh).

${ }^{3}$ War of the Gaedhil with the Gaill. p. I5I.

Ib., pp. 15I-I9r; Njáls Saga, chs. 155-157, Annals of Lock Ce, A.D. Ior 4 ; Annals of the Four Masters, A.D. Ior3. 
After the Battle of Clontarf the Norsemen became gradually absorbed in the general population except in a few coast towns, where they continued to live more or less distinct and governed by petty kings until the English Invasion (II69). In the chronicles of the twelfth and thirteenth centuries they are generally alluded to as "Ostmen" (corruptly Houstmanni, Nosmani, etc.), ${ }^{1}$ and it would seem that when Dublin, Limerick, and Waterford were captured by the English the "Ostmen" had to withdraw to certain districts outside the walls of these towns. Thus, near Dublin, north of the River Liffey, we hear of Ostmaneby' (i.e., Austmannabyr) afterwards called Ostmanstonry, and now known as Oxmanstown. Mention is also made (c. I200) of a " 'cantred' of the Ostmen and holy isle," near Limerick and (c. I282) of a "vill of the Ostmen "3 near Waterford." In the records of the fourteenth century, however, there is an almost total absence of references to the "Ostmen " in Ireland. ${ }^{5}$

${ }^{1}$ Calendar of the Ancient Records of Dublin (ed. by J. T. Gilbert), II. $8 \mathrm{I}$; Chartularies of St. Mary's Abbey, Dublin (ed. by Gilbert), I. 258 ; II. 25 I ; Giraldus Cambrensis : Topographia Hibernica, V. I 87.

The name "Ostmen" is generally supposed to have been first given to them by the English, but the word is Norse (i.e., Austmenn, plural of Austmathr, " a man living in the East") and therefore must have been current in Ire!and before the English invasion. It may be suggested that the name was applied to the original Scandinavian settlers in Ireland, to merchants and other later comers from Norway, Sweden, and Denmark. Cf. the nickname Austmathr, given to a certain Eyvindr by the Scandinavian settlers in the Hebrides because he had come there from Sweden.

${ }^{2}$ Chartularies of St. Mary's Abbey, I. 267 ; ib., I. 227, 234, etc.; Calendar of the Ancient Records of Dublin, I. 55 ; II. 96.

${ }^{3} A$ Calendar of Documents Relating to Ireland (ed. by HI. S. Sweetman), I. 24 .

Ib., II. p. 426 .

5or interesting articles on the Ostmen in Ireland see A. Bugge : Sidste Afsnit af Nordboernes Historie $i$ Irland, pp. 248-3 5 (Aarb ger for nord. Oldk. 1900); and E. Curtis : The English and the Ostmen in Ireland (English Historical Review, XXIII., p. 209 ff.). 
CHAP'IER II.

\section{INTERCOURSE BETWEEN THE GAILL AND THE GAEDHIL DURING THE VIKING PERIOD.}

THE existence of the Gaill-Gaedhil or foreign Irish in U1ster and various parts of Munster ${ }^{1}$ during the years $854-856$ shows that even in the early part of the ninth century there must have been considerable intercourse between the Vikings and the native population. For some of the GaillGaedhil were partly of Irish, partly of Norse extraction; others, as the annalist explicitly states, were Irishmen who had been fostered by the Norsemen, and in consequence had forsaken Christian practices and lapsed into Paganism. ${ }^{2}$ From a chance allusion in a tenth century text ${ }^{3}$ it would seem that they could speak Gaelic, but so badly that the expression "the gicgog of a Gall-Gaedheal " was generally understood to mean halting or broken Gaelic.

They are mentioned in the Annals for the first time in 854, in which year Aedh Finnliath, King of Aileach, won

1 Annals of Ulster, A.D. 855, 856; Annals of the Four Masters, A.D. 856 .

2 Three Fragments of Annals, pp. 128, $129 ; 138,139$.

3 Airec Menmam Uraird Maic Coisse, sec. 29 (Marstrander: Bidrag til det Norske Sprogs Historie i Irland, p. Io).

- Witls the Gaill-Gaedlil are often identified a body of plunderers, members of Meath and Cavan clans, who in the year 845 derastated large tracts of territory " after the manner of the Gentiles" (Annals of Ulster, A.D. 845). The Annalists call them " sons of death" (maic bais), possibly a term applied by the monastic chroniclers to a people who had abandoned their Christian baptism, and who had profaned churches and religious houses. (Cf. Marstrander, op. cit., p. 7, в.) 
a great victory over them in a battle fought at Glenelly, in Tyrone. ${ }^{1}$ After this they took an active part in the Irish wars, fighting like mercenaries on different sides-at one time in alliance with the $a r d-r i$, Maelsechnaill, who was at war with the Norsemen ; ${ }^{2}$ again, with an Irish clan against the Dublin Vikings under Ivarr, ${ }^{3}$ and still later we find them joined with the men of Waterford in opposition to the drd-ri." Led by Caittil Find (O.N. Ketill + Ir. find -fair) they made their last stand against the Dublin Vikings under Olaf and Ivarr, but were defeated with heavy losses, and after this there is no further record of their activities in Ireland. ${ }^{5}$ On one occasion at least, they fought

1 Cf. Annals of the Four Masters, A.D. 854. Three Fragments of Annals, A.D. 852 , referring to the same event, mention the "fleet of the Gaill-Gaedhil."

Annals of Ulster, A.D. 855.

${ }^{3}$ Annals of the Four Masters, A.D. 856.

- Fragments of Annals, A.D. 858 .

5 There was also a mixed Norse and Gaelic population in Galloway (the word is a corruption of Gall-Gaedhil, Welsh Galwydel) as well as in the Hebrides (Ir. Innse Gall., i.e., the "Islands of the Foreigners or Norsemen ") and other parts of Scotland. There is a reference to these Gaill-Gaedhill in the Four Masters (A.n. II 54): "The Cinél Eoghain and Muirchertach, son of Niall, sent persons over the sea to hire the fleets of the Gaill-Gaedhil of Aran, Cantire and the Isle of Man and the borders of Scotland in general, over which Mac Sgelling was in command"..... (For other references see Marstrander, op. cit., p. 9.)

By Gaddgethlar the Norsemen understood "the place . . where Scotland and England meet" (cf. Orkneyinga Saga, ch. 28). It is also interesting to note that in Norse sources the inhabitants of Galloway are called Vikinga-Skotar, a direct translation of Gaill-Gaedhil.

O'Flaherty (Ogygra, p. 360) thought that the Gaill-Gaedhil mentioned in the Annals of the mid-ninth century came to Ireland from Scotland, but the ancient Three Fragments of Annals, which contain the fullest accounts of the Gaill-Gaedhil (pp. I38-r4I) speak of them as Scuit (i.e., an Irish form of the Latin Scoti, a word which is always used with reference to the Irish before the tenth century). Moreover, the impression received from reading the Fragments of Annals is that the Annalist had in his Inind the Norse-Gaelic population of Ireland, not of Scotland. 
with the Viking armies in England. According to the account of the siege of Chester (c. 9I2) preserved in the Three Fragments of Annals, many Irishmen, foster-children of the Norsemen, formed part of the besieging army under the chieftain Hingamund, ${ }^{1}$ who had been expelled from Dublin some time previously. To these Irishmen Aethelflaed, the lady of the Mercians, sent ambassadors appealing to them as "true and faithful friends" to abandon the "hostile race of Pagans" and to assist the Saxons in defending the city. The Irish then deserted their former allies and joined the Saxons, "and the reason they acted so towards the Danes," adds the chronicler, "was because they were less friendly with them than with the Norsemen." "

The Vikings who formed settlements in Ireland during the reign of Turgeis $(839-845)$ seem to have mingled freely with the Irish, for we find them not long after their arrival stirring up the clans to rebellion against the $a r d-r i^{3}$ and joining the native princes on plundering expeditions. The annals mention several such alliances. Cinaedh, Prince of Cranachta-Breagh, who had revolted against Maelsechnaill with a party of plunderers, laid waste the country from the Shannon eastward to the sea. Another Irish prince, Lorcan, King of Meath, accompanied Olaf and Ivarr when they broke into the famous burial-mounds ${ }^{5}$ at New Grange, Knowth and Dowth, on the Boyne, and carried off the

1 Ann. Cambriae, A.D. 902 ; (Steenstrup: Normannerne, III., pp. $37-4 \mathrm{I})$.

Three Fragments of Annals, p. 230 ff.

Annals of the Four Masters, A.D. 845, 852; Annals of Ulster, A.D. 846 . Three Fragments of Annals, A.D. 862 .

4 Annals of the Four Masters, A.D. 848 .

"The plundering of these burial-mounds-" a thing that had never been done before "-made a deep impression on the Irish Annalists ; it was thought that the Vikings discovered the existence of the treasure by magic, "through paganism and idol worship" (War of the Gaedhil with the Gaill, p. II5). The same source (p. 25) records 
treasures which they found there. After the great naval battle between Danes and Norsemen in Carlingford Lough (A.D. 852) Danes and Irish frequently united forces against the common enemy, and on one occasion-after the two armies had won a victory over the Norsemen in Tipperary - the Danish chieftain Horm and his men were escorted in triumph to Tara where they were received with great honour by the ard-ri. ${ }^{1}$ Even after the arrival of Olaf the White, who brought about a temporary reconciliation between the two parties of "Foreigners," a detachment of Danes remained on in the service of Cearbhall, King of Ossory. ${ }^{2}$

The Irish chronicler, in alluding to the Norse practice of billeting their soldiers in the Irish farmhouses, lays stress on the feelings of hostility entertained by the Irish towards this "wrathful, foreign, purely Pagan people." Yet, we not infrequently find instances of friendly intercourse, as in the well-known story of Olaf-'Trygvason and the peasant. ${ }^{3}$ It appears that after Olaf's marriage to Gyda, sister of Olaf Cuaran, he occasionally visited Ireland. Once he sailed there with a large naval force, and being short of provisions went on land with his men on a foraging expedition. They

the plundering of Kerry by Baraid (O.N. Barthr) and Olaf the White's son " who left not a cave there und.rground that they did not explore."

Several references to this practice of the Vikings occur also in Icelandic literature. It is interesting to compare the Irish accounts with the following passage from Landnámabók (I., ch. 5) : "Leifr (one of the earliest settlers in Iceland) went on a Viking raid to the West. He plundered Ireland and found there a large underground house (Icel. jarth-hus). It was dark within until he made his way to a place where he saw a light shining from a sword which a man held in his hand. Leifr slew the man and took the sword and much treasure besides."

${ }^{1}$ Three Fragments of Annals, p. 135.

Ib., p. 137.

Heimskringla : Oldfs Saga Tryggvasonar, ch. 35. 
seized a large number of cows, and were driving them towards the shore when a peasant ran after them and begged Olaf to give him back his cows. Olaf told him to take them, if he could separate them from the rest without delaying their journey. The peasant had with him a large sheepdog, which he sent in among the herd, and the dog ran up and down and drove off as many cows as the peasant claimed. As they were all marked in the same way it was evident that the dog knew all his master's cows. Then Olaf asked if the peasant would give him the dog. "Willingly," was the reply. So Olaf gave him in return a gold ring, and assured him of his friendship. The dog was called Vígi, "the best of all dogs," and Olaf had it for a long time. Years later, after the great naval battle in which Olaf lost his life, "Vígi lay on a mound and would take no food from anyone, although he drove away other dogs and beasts and birds from what was brought to him. . . Thus he lay till he died."1

Moreover, the evidence of both Norse and Irish sources goes to show that all through the ninth and tenth centuries there was extensive intermarriage between the two peoples. Marriages of the invaders with the women whom they had carried off as captives must have taken place from an early period, ${ }^{2}$ and we know definitely that the kings and chieftains on both sides frequently strengthened their alliances by unions between members of the royal families. According to the Landnamabók many distinguished Icelanders traced their descent to Kjarval, i.e., Cearbhall,

'Cf. The story of Samr, (i.e., probably Ir. sam, "happy" or "peaceful") the Irish hound which Olaf Pai gave to Gunnarr. Samr was killed while defending his master's homestead. (Njáls Saga, chs. 69, 75.)

2 Annals of the Four Masters, A.D. 820; Fragments of Annals, p. 166; War of the Gaedhil with the Gaill, p. 79; The Victorious Career of Callachan of Cashel, p. 9. 
King of Ossory (d. 887), an ally of Olaf and Ivarr. His grandson, Dufthak (Ir. Dubhthach) ${ }^{1}$ was the founder of an Icelandic family, and three of his daughters, Kormlöth (Ir. Gormflaith), ${ }^{2}$ Frithgerth ${ }^{3}$ and Rafarta ${ }^{4}$ married Norsemen. The Landnamabok speaks of Kjarval as having been King of Dublin while "Alfred the Great ruled in England ... and Harold Fairhair in Norway," 3 a statement which is often doubted because unsupported by the evidence of the Irish historians; but it is not at all unlikely, since Cearbhall was remotely connected with the Dublin royal house through his granddaughter Thurithr, who married Thorsteinn the Red, son of Olaf the White. ${ }^{\circ}$

There is no mention of Authr, Olaf's Norse wife, in the Annals, but we hear incidentally ${ }^{7}$ that Olaf, while in Ireland, married a daughter of Aedh Finnliath, King of Aileach. After he became ard-ri (864) Aedh turned against the Norsemen, and having plundered all their fortresses in the north of Ireland marched towards Lough Foyle, where they had assembled to give him battle. Aedh was victorious, and some years after he again defeated the Foreigners, who were at this time in alliance with his nephew Flann; Flann himself and Carlus, son of Olaf the White being

${ }^{1}$ Landnámabók, V., clı. 8.

2 Ib., V., ch. I3.

Ib., JII., ch. 9.

4 Ib., III., ch. 12. Rafarta was the wife of Eyvindr the Easterner, "who settled down in Ireland and had charge of Kjarval's defences" (cf. Grettis Saga, ch. 3). Orkneyinga Saga (ch. 11.) makes Edna (Ir. Eithne) another of Kjarval's daughters to be the mother of Sigurthr, Earl of Orkney (killed in the battle of Clontarf, ror4); but owing to the chronological difficulty this is hardly likely.

${ }^{5} L a n d n a ́ m a b o ́ k$, I., ch. I.

'Ib., II., ch. 15.

"Three Fragments of Annals, p. 151. The same source (p. 173) mentions still another wife of Olaf, "the daughter of Cinaedh," i.e., in all probability Cinaedh Mac Ailpin, King of the Picts (d. 858). 
numbered among the slain. We also hear of other Irish Kings who were closely related to their Viking opponents. Laxdaela Saga contains an interesting account of a slavewoman who was bought at a market in Norway by an Icelander called Höskuldr. The woman was dumb, but Höskuldr was so struck by her appearance that he willingly paid for her three times the price of an ordinary slave, and took her back with him to Iceland. A few years later, happening to overhear her talking to their little son, Olaf Pá, he discovered to his amazement that her dumbness was feigned. She then confessed that her name was Melkorka (Ir. Mael-Curcaigh) and that she was the daughter of Myr Kjartan, a king in Ireland, whence she had been carried off as a prisoner of war when only fifteen years old.

When Olaf was grown up his mother urged him to visit Ireland in order to establish his relationship with King Myr Kjartan, " for," she said, "I cannot bear your being called the son of a slave-woman any longer." Before they parted she gave him a large finger-ring and said: "This my father gave me for a teething-gift, and I know he will recognise it when he sees it." She also put into his hands a knife and belt and bade him give them to her nurse: "I am sure she will not doubt these tokens." And still further Melkorka spoke: "I have fitted you out from home as best I know how, and taught you to speak Irish, so that it will make no difference to you where you are brought to shore in Ireland. ...."1

The saga goes on to describe the voyage to Ireland, the landing there, and Olaf's reception by King Myr Kjartan.

Myr Kjartan may be identified with Muirchertach " of the Leather Cloaks," King of Aileach, who like his father Niall Glundubh distinguished himself by his spirited

${ }^{1}$ Laxdaela Saga (translated by M.A.C. Press), clus. I2, 13, 20, 21. 
resistance to Norse rule in the first half of the tenth century. ${ }^{1}$ Donnflaith, another of his daughters and mother of the $d r d-r i$, Maelsechnaill II., married Olaf Cuaran. Their son, Gluniarainn, reigned in Dublin after his father's retirement to Iona, and appears to have been on friendly terms with Maelsechnaill. ${ }^{2}$ The relationship between these two families becomes more complicated owing to the fact that Maelsechnaill's own wife, Maelmuire (d. I02I), was a daughter of Olaf. ${ }^{3}$

But perhaps no figure stands out so prominently in the Irish and Norse chronicles ${ }^{4}$ of the second half of the tenth century as Gormflaith (O.N. Kormlöth) who first married Olaf Cuaran, then his enemy Maelsechnaill II., and finally Brian Borumha, from whom she also separated.

The interchange of family and personal names which took place to such an extent during the Viking period also points to the close connection between the foreigners and the Irish. As early as 835 mention is made of one Gofraidh (O.N. Guthröthr), son of Fergus, who went to Scotland from Ireland in order to strengthen the Dal Riada and died some time after as King of the Hebrides. ${ }^{5}$ The Dublin Viking who led an attack on Armagh in 895 had an Irish name, Glun-iarainn, obviously a translation of O.N. Jarn-kné. He was in all probability a relative of Iercne or Jargna (corrupt forms of Jarn-kné) who ruled in conjunction with

1 The Annals of the Four Masters record his death under the year 94I: "Muirchertach of the Leather Cloaks, lord of Aileach, the Hector of the West of Europe in his time, was slain at Ardee by Blacaire, son of Godfrey, lord of the Foreigners."

Muirchertach's grandson was killed by Olaf Cuaran. (Ib., A.D. 975).

2 Ib., A.D. 98 I.

3 Ib., A.D. IO2I.

-War of the Gaedhil with the Gaill, p. 142 ff.; Njáls Saga, chs. 153, 154 .

Annals o the Four Masters, A.D. 85 I. 
Zain or Stain (O.N. Steinn) as King of Dublin (c. 850) $;^{1}$ while other earls of Dublin, Otir mac Eirgni, Eloir mac Ergni or Largni ${ }^{3}$ and Gluntradna, son of Glun-Iarainn would also appear to have been of the same royal family." Irish names occur more frequently in Norse families during the tenth and eleventh centuries; we find Uathmaran, son of Earl Bairith (O.N. Barthr) ; Camman, son of Olaf Godfreyson; Giolla Padraig, Dubhcenn ${ }^{8}$ and Donndubhan, sons of King Ivarr of Limerick ; Niall, son of Erulb (O.N. Herjulfr); Cuallaidh, son of King Ivarr of Waterford; Eachmarach, and very many others. ${ }^{8}$ On the other hand, we may note the prevalence of such common Norse names as Ivarr, Guthröthr, Sumarlithi among the Irish, especially in the eleventh and twelfth centuries. Several of these names still survive, as, for instance, MacAuliffe (O.N. Oláfr); MacCaffrey (O.N. Guthöthr); MacCalmont or

${ }^{1}$ Three Fragments of Annals, pp. 119, 123. Annals of Ulster, A.D. 852 .

${ }^{2}$ Chronicon Scotorum, A.D. 883 .

3 Ib., 886; Annals of Ulster, A.D. 885.

- See A. Bugge: Nordisk Sprog og Nordisk Nationalitet, i Irland, pp. 284, 285. Professor Marstrander (op. cit., pp. 45, 46) takes Gluntradna to be an Irish adaptation of an O.N. nickname Trönu-Kné, to which he compares Trönubeina, the daughter of Thraell, in the Rigsthula, 9.

${ }^{5}$ Cf. the name Grimr Kamban (Landnámabók, Hauksbók MS., ch. 19) which seems to be a Norse form of the Irish Camman.

- According to A. Bugge, Dubhcenn is a translation of the O.N. Svarthofthi, but Marstrander (op. cit., p. 45) holds that the name was known in Ireland before the Viking age. It may be suggested that it was a nickname given to Ivarr's son by the Irish. Cf. Olaf Cuaran (Ir. cuaran, a shoe made of skin); Olaf Cenncairech (i.e., "Scabbyhead.")

'Their mother was an Irishwoman, sister of Donnabhan, King of Ui Fidgenti. Donnabhan himself was married to a daughter of Ivarr, King of Limerick. (War of the Gaedhil with the Gaill, p. 207).

- Annals of the Four Masters, A.D. 931; Annals of Ulster, A.D. 960, 1036, 1042, etc. See also Whitley Stokes: On the Gaelic Names in the Landnámabsk (Revue Celtigue, III., pp. 186-19I). 
Lamont (O.N. Lögmathr); Kettle (O.N. Ketill); Kitterick (? Ir. Mac +N. Sigtryggr); MacKeever (O.N. Ivarr); Manus and MacManus (O.N. Magnus) ; Quistan (Ir. Mac. + O.N. Eysteinn); Reynolds (O.N. Rögnvaldr) ; Sigerson (O.N. Sigurthr) and MacSorley (O.N. Sumarlithi).

Both Gaill and Gaedhil, so dissimilar in many ways, benefited by their intercourse with one another. In Ireland the Vikings played an important part in the development of trade; they also promoted the growth of town life. We may trace the beginnings of the seaport towns, Dublin, Limerick, Waterford and Wexford, to the forts built by them near the large harbours in the ninth and tenth centuries. In Dublin coins were minted for the first time in Ireland ${ }^{1}$ during the reign of Sihtric Silken Beard (c. 989-I042). Moreover, the large number of loan-words from Old Norse which made their way into Irish shows that the Irish learned in many other ways from the invades, notably in shipbuilding and navigation.

So far as literature and art are concerned, the period of the Viking occupation is one of the most interesting in the history of Ireland. In spite of the destruction of the monasteries and the departure of numbers of the monks ${ }^{2}$

${ }^{1}$ From the contemporary Irish poems the Book of Rights and The Curcuit of Muirchertach Mac Neill it may be inferred that in ancient Ireland all payments were made in kind. With the extension of trade, however, it is probable that many Anglo-Saxon and other foraign coins-including those of the Scandinavian Kings of Northumbria, several of whom also reigned in Ireland-came to be circulated in Ireland. The Vikings in England struck coins there during the reign of Halfdanr (d. 877). (Cf. C. F. Keary : Catalogue of Coins in the British Museum, I., p. 202).

One of these fugitives wrote the following lines on the margin of Priscian's Latin Grammar in the monastery of St. Gall, Switzerland:

"Is acher ingaith innocht fufuasna fairge findfolt,

Ni agor reimm mora minn dond laechraid lainn na lothlind."

(Thesaurus Palaeohibernicus: Ed. Stokes and Strachan, II., 290.) 
to the Continent the work of the great schools was carried on and there was considerable literary activity $;^{1}$ in 914 and 924, respectively, the great crosses at Clonmacnois and Monasterboice were set up ; cumhdachs, or book-shrines of plated gold and silver, were made for the three great manuscripts, the Book of Kells, the Book of Durrow and the Book of Armagh; carved gold, silver, and bronze work reached a high level of excellence in the famous Ardagh Chalice and the Tara Brooch; and during the years which intervened between the battles of Gleann Mama and Clontarf, Romanesque architecture was introduced into Ireland. Irish art did not remain wholly free from Scandinavian influence. In the Cross of Cong (A.D. II23) the Celtic interlaced patterns are found side by side with the "wormdragon" ornament, while the crosier of Clonmacnois, the psalter of Ricemarsh and the shrine of St. Patrick's Bell are decorated in the style known as "Hiberno-Danish."

The Vikings, on the other hand, came under the influences of Irish art and literature. We find marks of Celtic influence not only in the sculptured crosses erected by the Norsemen in the North of England and Man, but even in Scandinavia itself. $^{3}$ Moreover, there are strong reasons for supposing that the rise of the prose saga among the Icelanders may be the outcome of their intercourse with the Irish in the ninth and tenth centuries.

2.e., Bitter is the wind to-night,

It tosses the ocean's white hair ;

To-night I fear not the fierce warriors of Norway

Coursing on the Irish Sea.

(Translation by Kuno Mejer : Ancient Irish Poetry, p. 101.)

1 See Margaret Stokes: Early Christian Architecture in Ireland, p. 127 .

2 G. Coffey: A Guide to the Celtic Antrquities of the Christian Period (National Museum, Dublin) pp. 29, 49 and 62.

Ib., p. 17. 


\section{CHAPTER III.}

\section{THE GROWTH OF THE SEAPORT TOWNS.}

THE foundation of the seaport towns was the most important, and at the same time the most permanent effect of the Viking invasion of Ireland. Before this the only towns were the larger monastic centres ${ }^{1}$ at Armagh, Clonmacnois, Durrow and Clonfert, which, besides the monastery itself, consisted of numerous beehive-shaped houses of stone, or small huts of clay and wattles built for the accommodation of the students attending the schools. During the first half of the ninth century these monasteries suffered sorely from the attacks of Viking raiders. After a stubborn resistance on the part of the Irish, Armagh fell into the hands of Turgeis, who drove out the abbot Farannan and " usurped the abbacy" (c. A.D. 839). Some years later Armagh was abandoned when the Vikings captured Dublin, at this time a small " town by the hurdle ford,"' 2 but they were quick to realise its possibilities as the seat of their monarchy and the chief centre of their trade. As a result of the struggle for ecclesiastical supremacy, which took place at a later period $^{3}$ between Armagh and Dublin, the Bishops of Dublin were obliged to acknowledge the Primate of Armagh;

1 In the Annais of Tighernach (A.D. 716), the Annals of Ulster (A.D. 7I5), and the Book of Hymns (ed. Todd, p. I56) the Latin civitas (Ir. Cathair) is the word used for a monastery.

2 The old name for Dublin was Baile-atha-Cliath, "the town of the hurdle ford." It was afterwards called Dubh-linn (" black pool "), of which the O.N. Dyflin is a corruption,

3 See p. 55. 
but the latter town never recovered its former prestige as the capital of Ireland. ${ }^{1}$

That Dublin owes its importance, if not its origin, to the Norsemen may be inferred from the almost total silence of the historians and annalists regarding it in the years preceding the Scandinavian inroads. It is probable that there was a fort to guard the hurdle-ford where the great road from Tara to Wicklow, Arklow and Wexford crossed the Liffey, but it seems to have played no great part in history before the Norsemen fortified it in 840. Between Church Lane and Suffolk Street they had their Thing ${ }^{2}$ or meetingplace, which was still to be seen in the seventeenth century ; while all along College Green, called Le Hogges ${ }^{3}$ and later Hoggen Green by the English, lay their barrows (O.N. haugar). During the ninth and tenth centuries the Kingdom of Dublin-known to the Scandinavians as Dyflinarskibecame one of the most powerful in the west. Its sway extended north to its colonies ${ }^{4}$ at the Strangford and

1 Armagh is the only place in Ireland which is marked on a tenth century map of the world preserved in the British Museum. See R. A. S. Macalister : Muiredach: Abbot of Monasterboice, p. I3.

2 It is called Tengmonth and Teggemuta in medieval documents (Chartularies of St. Mary's Abbey, I., 15, 461, 463, 465) and from it the surrounding parish of St. Andrew-"Parochia Sancti Andreae de Thengmote" - took its name. In $6_{47}$ it is referred to as "the fortified hill near the College," but about thirty years later it was levelled to the ground and the earth was used for building Nassau Street (J. T. Gilbert - History of Dublin, II , p. 258).

3 The name survived until the I8th century in $\mathrm{Hog} H i l l$, but it wes afterwards changed to St. Andrew's Street.

- Annals of Ulster, A.D. 839, 840, 925, 928, 934 .

These colonies were governed by earls, not kings, and their dependency on the kingdom of Dublin is clearly shown by certain entries in the Annals. In 926 a Viking fleet at Linn Duachaill (on the coast of Louth) was commanded by Albdarn (O.N. Halfdanr), son of Guthfrith (King of Dublin, 920-933). Later, when part of Albdann's army was besieged at Ath Cruithne (near Newry), 
Carlingford Loughs, west to Ieixlip, south to Wicklow, Wexford ${ }^{1}$ and even as far as Waterford. The Dublin kings intermarried with royal families in Ireland, England and Scotland, and between the years 9 I9 and 950 ruled, though in somewhat broken succession, as Kings of York.

Limerick (O.N. Hlymrek) ${ }^{2}$, the great stronghold on the west coast, had no existence as a city before the ninth century. It was first occupied during the reign of Turgeis by Vikings, who used the harbour as a base for their ships. ${ }^{3}$ The only chieftains mentioned in connection with this kingdom during the ninth century are Hona and Tomrir Torra (O.N. Thórarr Thórri), who were slain about the year 860 in attempting to capture Waterford. ${ }^{4} \mathrm{~A}$ few years later Barith (O.N. Barthr) and Haimar (O.N. Heimarr) when marching through Connacht on their way to Limerick, were attacked by the Connachtmen and forced to retreat. The real importance of Limerick, however, dates from the early part of the tenth century when it was colonised by Vikings under Tomar (Thórir) son of Elgi (O.N. Helgi). To secure the fort against attack an earthen mound was built all round, and gates were placed at certain distances

Guthfrith went with his forces to relieve it. In 927 the "foreigners of Linn Duachaill" accompanied Guthfrith when he marched on York. See Steenstrup, op. cit., III., p. II5.

${ }^{1}$ Wexford was also governed by earls. One of thein, Accolb, is mentioned in the Annals of the Four Masters, A.D. 928.

2 The Irish name Luimnech (hence O.N. Hlymreh) was originally applied to the estuary of the Shannon, but was afterwards confined to the town itself when it had risen to importance under Scandinavian rule.

S Annals of the Four Masters, A.D. 843; War of the Gaedhil with the Gaill, p. 8.

Three Fragments of Annals, pp. I67, 144-6. War of the Gaedhil with the Gaill, ch. 23 .

Three Fragments of Annals, pp. 173-175; Chronicon Scotorum, A.D. 887 . 
leading into the streets and the houses. ${ }^{1}$ As a kingdom it was independent, baving subject colonies at Cashel, Thurles, Irough Ree and Lough Corrib. ${ }^{2}$ It bad no connection with Dablin during the tenth century ; in fact, there is evidence to show that both royal houses were bitterly bostile towards each another. On one cccasion Guthfith, King of Dublin, led an army to Limerick, but was repulsed with heavy losses by the Vikings there. ${ }^{3}$ A few years later (A.D. 929) he expelled Tomar's successor, King Ivarr of Limerick, and his followers from Magh Roighne (a plain in Ossory), where they had encamped for a whole year. Olaf Godfreyson was equally active. After defeating Olaf Cenncairech and the Limerick Vikings at Lough Ree in 937, he carried them off to Dublin, and that same year probably furced them to fight on his side in the battle of Brunnanburh.

This hostility would seem to have been due to rivalry between two powerful kingdoms, rather than, as has been suggested, ${ }^{5}$ to difference of nationality. It is not at all certain that the Limerick Vikings were purely Danes. One Irish chronicler speaks of the Scandinavians in Munster as Gaill and Danair and calls their fleets loingeas Danmarcach ocus allmurach ("fleets of Danes and foreigners "). ${ }^{6}$ Elsewhere ${ }^{7}$ we find the word Lochlannaigh (i.e., Norsemen) used with reference to the Limerick settlers ;

${ }^{3}$ The Victorious Career of Cellachan of Cashel, pp. 9, 66; War of the Gaedhil with the Gaill, p. 56.

2 Annals of Ulster, A.D. 845, 922, 929; The Victorious Career of Cellachan of Cashel, p. Io; War of the Gaedhil with the Gaill, p. 10; Three Fragments of Annals, p. 197.

Annals of Ulster, A.D. 924.

- Annals of the Four Masters, A.D. 935 ; Chronicon Scotorum, A.D. 936.

${ }^{5}$ A. Bugge : Sidste Afsnit af Nordboernes Historie i Irland, pp 254,255 .

- War of the Gaedhil with the Gaill, p. 4I.

'The Victorious Career of Cellachan of Cashel, p. 64. 
Fand Colla (O.N. Kolli), Prince of Limerick (d. 93I) was certainly a Norseman, for he was son of Barthr, a leader of the Finn-Gennti in the ninth century. There would seem to have been a mixture of both Danes and Norsemen in Limerick, and since there is no proof that struggles for mastery took place between them, we may take it that they acted in harmony.

During the tenth century Iimerick stood in close connection with the Scandinavian Kingdom in the Hebrides. ${ }^{3}$ Mention is made of one chieftain "Morann, son of the Sea King of Lewis," 2 who fought and fell in Limerick against the Irish. Moreover, the occurrence of the names Manus, Maccus (O.N. Magnus) and Somarlidh (O.N. Sumarlithi) in both royal families points at least to relationship by ma1riage. Indeed, the same family seems to have reigned in both kingdoms. "Godfrey, won of Harold, King of the Hebrides," who was slain by the Dal Riada in $989^{3}$ was in all probability a son of that "Harold, lord of the foreignets of Limerick," whose death is recorded by the Four Masters in 940.

Practically nothing is known of the Scandinavian settlement in Waterford (O.N. Vethrafjorthr) before the year 9r9, when Vikings under Raghnall (O.N. Rögnvaldr), " King of the Danes," concentrated their forces there before attacking Dublin. These invaders, sometimes called Nortmannai ('Norsemen'), but generally alluded

1 Steenstrup : op. cit., III., p. 213.

2 The Victorious Career of Cellachan of Cashel, p. 65.

3 Annals of Ulster, A.D. 988.

"Three Fragments of Annals (A.D. 860) record that "two flects of the Norsemen came into the land of Cearbhall, son of Dunlaing (King of Ossory) to plunder it." These fleets probably sailed up the Barrow from Waterford harbour. The same annals also mention (p. I29) a Norse chieftain called Rodolbh, who may have been connected with the coloyy at Waterford. See also Annals of the Four Masters, A,D, 888 [89r]. 
to as Gaill ('foreigners ') must have also included Danes, as Raghnall's army was composed of both Danes and Norsemen $;^{1}$ and moreover, both parties are represented as fighting side by side against the Irish in Waterford.2

Waterford had not at first a dynasty of its own, but was dependent on the Dublin Kingdom. Olaf Godfreyson seems to have been in command there while his father was King of Dublin $;^{3}$ and we hear also that when the town was attacked by the Irish under Cellachan of Cashel, Sibtric, a prince from Dublin, came with a fleet to relieve it." Later in the same century, the kingdom of Waterford stood quite distinct, and was governed by Ivarr (d. I000), who was probably a member of the Dublin royal family. He came forward as a claimant to the Dublin throne after the murder of Gluniarainn, son of Olaf Cuaran (989) but was driven out after a three years' reign by Sihtric Silken-Beard. Ivarr's successors in Waterford, Amond (O.N. Amundr) and Goistilin Gall were killed in the battle of Clontarf.

In the tenth and eleventh centuries Waterford was strongly fortified, and, like Limerick, had gates leading into the town.s The town itself was built in the form of a triangle with a tower at each angle, ${ }^{6}$ only one of which, the famous Reginald's Tower, built in 1003 , is still standing. Gualtier (? Ir. Gall tir, 'land of the foreigners'), a barony lying on the west side of the harbour, is supposed to have been connected with the 'Ostmen,' who were obliged to settle there after the arrival of the English in II69.

1 Annals of Ulster, A.D. 921.

${ }^{2}$ The Victorious Career of Cellachan of Cashel, p. $7 \mathrm{I}$.

3 The Four Masters record " the plundering of Kildare by the son of Gothfrith (i.e., Olaf) from Waterford" (A.D. 926).

- The Victorious Career of Cellachan of Cashel, p 70.

-The Victorious Career of Celluchan of Cashel, pp. 13, 70.

6 Smith : History of Waterford, p 165. 
Cork, the seat of a famous school founded by St. Finbar, fell an easy prey to the Vikings in the first half of the ninth century. They built forts there and at Youghal, ${ }^{1}$ but in endeavouring to push their way inland to Fermoy were checked by the Irish (866), and their chief, Gnimcinnsiolla (or Gnimbeolu) ${ }^{2}$ was slain. We hear no more of Scandinavians here until early in the tenth century when new invaders, part of the large army which came to Waterford with Raghnall and Earl Ottarr in 9I9, gained possession of the town. The new settlers seem to have been chiefly, if not entirely, Danes (Danair and Duibhgeinnti), ${ }^{3}$ and it would seem that with the Danish colonies at Thurles and Cashel they subsequently came under the authority of Ivarr of Limerick, "the high-king of the foreigners of Munster."

Traces of the Scandinavian occupation still remain in the place-names on the coast, especially in the districts surrounding the seaport towns. Near Dublin we find Howth (O.N. höfuth, 'a head') and Skerries (O.N. skjar, 'a.rock' ; also Lambey, Dalkey and Ireland's Eye, all three containing the O.N. form ey, an ' island.' The name Leixlip is probably a form of O.N. laxhleypa" (' salmon-leap ') not, as is generally supposed, of O.N. lax-hlaup. The O.N. fjörthr occurs in Wexford, Strangford and Carlingford

1 Annals of the Four Masters, A.D. 846,864 .

2 Ib., 865. Fragments of Annals, p. I69,

Gnimbeolu is the O.N. Grimr Biola. The Irish "Cinnsiolla" (Nom. Cenn Selach) is probably a translation of O.N. Selshofuth, a word which does not occur as a nickname in Old Norse literature. It was, however, known in Ireland as may be seen from the runic inscription-domnal Selshofoth a soevth $(t h)$ eta-on a bronze sword. plate found in Greenmount (Co. Lout11). Cf. Marstrander, op. cit. p. 49.

${ }^{3}$ The Victorious Career of Cellachan of Cashel, pp. ro, 67.

'Cf. Marstrander, op. cit., p. I49. 
(O.N. Kerlingafjörthr). 1 Other Scandinavian names on the east coast are Copeland Islands (i.e., Kaupmannaeyjar, 'the merchants' islands ') near Belfast Lough ; Arklow, Wicklow (O.N. lo, a low, flat meadow by the water's edge.) ; Carnsore and Greenore (O.N. eyrr, ' a small tongue of land running into the sea ').

The number of names on the south and west coasts is limited; besides Waterford, we find only Helvick (O.N. vik, 'a bay'), Dursey Island, south-west of Cork, and Swerwick Harbour, in Kerry. At least three wellauthenticated place-names have dropped out of use ; Dún na Trapcharla, in Co. Limerick (O.N. (I) torf-karl, 'a turf-cutter' or (2) thorp-karl, a 'small farmer');' Jolduhlaup, ${ }^{3}$ a cape in the north of Ireland; and Ulfreksfjörthr, the Norse name for Lough Lame.

It is also interesting to note that the second element in the names of the three provinces, Ulster, Leinster and Munster is derived from the O.N. stathir (plural of stathr, 'a place '), while the name Ireland (O.N. Iraland) is Scandinavian in form and replaced the old Irish word Eriu during the Viking period.

1 Cf. Marstrander, op. cit., p. 154. According to him, the O.N. Kering, " an old woman" in this instance, is a folk-etymological form of Carlinn, the old name for the ford.

${ }^{2}$ Annais of the Four Masters, A.D. ro62. Cf. Co dunad na Piscarcarla in Cath Ruis na Rig (ed. Hogan) where Piscarcarla corresponds to the O.N. fiskikari, " a fisherman."

The word Trapcharla (" na Trapcharla") al so occurs in the Book of Ballymote as the name of a people who fought at Troy. It has been suggested that the term was generally used during the ninth and tenth centuries of a Norse colony in Co. Limerick, which colony would acquire a legendary character after the Norsemen had been driven out of Ireland, and would figure, like the I,ochlannaigh or Norsemen, in Middle-Irish stories and poems.

See Miscellany presented to Kuno Meyer, pp. 293, 370.

'Landnámabók I. ch. I.

- Heimskringla : Saga Óldfs hins helga, chs. 88, ro. 
CHAPTER IV.

\section{THE EXPANSION OF IRISH TRADE.}

WhEN the Scandinavians had firmly established themselves on the Irish coasts they developed trade to a considerable extent, not only by bringing Ireland into communication with their new settlements in England, but also by opening up commerce with Iceland and Scandinavia, and even with Russia and the East. ${ }^{1}$ Before A.D. 900 at all events, they had been accustomed to visit France from Ireland, and had trafficked with merchants there, using a certain vessel called the 'Epscop' 2 for measuring their wine. That this branch of their trade was in a flourishing condition in the latter half of the tenth century may be inferred from a contemporary poem in which Brian Borumha is said to have exacted as tribute one hundred and fifty vats of wine from the Norsemen of Dublin, and a barrel of red wine every day from the Limerick settlers. ${ }^{3}$

The Scandinavians also made marked advances on the old methods of trading by building their forts near the large harbours and carrying on from there a continuous

'See the map of the Irish Trade Routes in Mrs. J. R. Green's The Old Irish World.

2"Epscop fina" in the sea-laws, i.e., " a vessel for measuring wine used by the merchants of the Norsemen and the Franks." See Sanas Cormaic (Cormac's Glossary) compiled c. A.D.900. (Anecdota from Irish Manuscripts IV., ed. Kuno Meyer.)

'Cf. O'Curry : Manners and Customs of the Ancient Irish, II., p. 125. For a transcript of the poem see A. Bugge: Vesterlandenes Indflydelse paa Novdboernes $i$ Vikingetiden, p. 183 . 
overseas commerce. ${ }^{1}$ Previous to this foreign merchants ${ }^{2}$ who visited Ireland used to exchange their goods for home produce at the numerous oenachs or fairs held at certain intervals all over the country. These oenachs continued to be celebrated during the Viking period, but it was in the seaport towns, Dublin, Limerick, Cork, Wexford, and Waterford, that the most important trade was centred. Dublin, owing to its splendid position, half way between the Continent and the Scandinavian settlements in Scotland and Iceland, and within easy distance of England, became one of the wealthiest towns in the West. One Irish chronicler gives a glowing account of the treasures carried off from there by the Irish after the battle of Gleann Máma (A.D. I000) :

"In that one place were found the greatest quantities of gold, silver, bronze, and precious stones : carbuncle-gems, buffalo horns, and beautiful goblets ... much also of various vestures of all colours were found there likewise." 3

Dublin is frequently mentioned in the sagas and seems to have been very well known to Icelandic dealers. In Olaf Tryggvason's Saga (Heimskringla) we read that during the reign of Olaf Cuaran a merchant called Thórir Klakka, who had been on many a Viking expedition, went on a trading voyage to Dublin, " as was usual in those days." When Olaf's son, Sihtric Silken Beard, was King of Dublin (c. 994) the Icelandic poet Gunnlaug Ormstungu sailed from England to Ireland with merchants who were bound for Dublin. ${ }^{5}$

1 Cf. Laxdaela Saga, ch 2 r.

2 According to an ancient poem on the great fair of Carman (Co. Kildare) foreign merchants visited this fair and sold there "articles of gold and silver, ornaments and beautiful clothes." For other references see Joyce: A Social History of Ancient Ireland, Vol. II., pp. 429-43I ; O'Curry: Manners and Customs of the Ancient Irish, III., p. $53 \mathrm{I}$.

3 War of the Gaedhil with the Gaill, p. II5.

- Saga Óláfs Tryggvasonar (Heimskringla), ch. 5 I.

- Gunnlaugs Saga Ormstungu, ch. 8. 
Eyrbyggia Saga tells ${ }^{1}$ of both 'Thórodd, the owner of a large ship of burden, and Guthleif, ${ }^{2}$ who went with other traders on voyages " west to Dublin." Still more interesting is the account in the same saga of a merchant-ship that came from Dublin in the year Iooo to Snaefellsness in Iceland and anchored there for the summer. There werc on board some Irishmen and men from the Sudreyar (Hebrides) but only a few Norsemen. One of the passengers, a woman named Thorgunna, had a large chest containing " bed-clothes beautifully embroidered, English sheets, a silken quilt, and other valuable wares, the like of which were rare in Iceland."'

Limerick is heard of only once in Icelandic sources; a trader named Hrafn was surnamed "the Limerick-farer" (Hlymreks fari)" because he had lived for a long time there. The War of the Gaedhil with the Gaill gives a detailed description of the spoils gained by the Irish after the battle of Sulcoit (968) whence it would seem that the Limerick Vikings had been engaged in trade with France, Spain and the East.

"They carried away their (i.e., 'The Vikings') jewels and their best property, their saddles, beautiful and foreign, their gold and their silver; their beautifully woven cloth of all colours and of all kinds; their satins and their silken cloths, pleasing and variegated, both scarlet and green, and all sorts of cloth in like manner." s

Reference has already been made to the numbers of Irish women captured by Viking raiders ; many of these captives were afterwards sold as slaves in Norway and Iceland. In Laxdaela Saga we hear of Melkorka, an Irish princess, who

1 Eyrbyggia Saga, ch. 29.

2 Ib., ch. 64.

${ }^{3} \mathrm{Ib}$., ch. 50.

${ }^{4} L a n d n a ́ m a b o ́ k$, II., ch. 21, etc.

'War of the Gaedhil with the Gaill, p. 79. 
was exposed for sale with elevell other women at a market in Norway. The slave-dealer, a man known as Gilli (Ir. Giolla) " the Russian" was in all probability a Scandinavian merchant from Ireland who had carried on trade with Russia. The extent of the slave traffic is further illustrated in Kristni Saga (ch. 3) where mention is made of "a fair Irish maid" whom Thangbrandr the priest bought; " and when he came home with her a certain man whom the emperor Otto the Young had put as steward there, wished to take her from him," but Thangbrandr would not let her go ! 1 On the other hand, the Irish frequently descended on the Viking strongholds in Ireland and carried off the Norse women and children, " the soft, youthful, bright, matchless girls ; blooming, silk-clad young women, and active, large well-formed boys." 2 Therefore it is not unlikely that the "slaves ignorant of Gaelic" who are stated to have been given as tribute to the Irish kings in the ninth and tenth centuries $^{3}$ were really Scandinavian prisoners of war.

An interesting passage in the Book of Ely gives an idea of the activity of the Irish merchants at this period: "Certain merchants from Ireland, with merchandise of different kinds and some coarse woollen blankets, arrived at the little town called Grantebrycge (Cambridge) and exposed their wares there." It is not surprising then that the wealth of Ireland increased rapidly, so much so that Brian Borumha, realising that this was largely due to Viking enterprise, allowed the invaders to remain in their forts on the coast "for the purpose of attracting commerce from

1 Kristni Saga, ch. 3.

2 War of the Gaedhil with the Gaill, p. 79.

${ }^{3}$ The Book of Rights (Leabhar na gCeart), pp. 87, 18x. Ed. J. O'Donovan.

- Liber Eliensis, (ed. Gale) I., ch. XIII. 
other countries to Ireland." 1 And even after their defeat at Clontarf, the Vikings remained in the coast towns, whence they continued to engage in trade witn England and the Continent. Botlı Giraldus Cambrensis ${ }^{2}$ and William of Malmesbury ${ }^{3}$ mention the extensive slave-trade carried on between Ireland and England in the twelfth century, Bristol being the chief centre. In addition to the slave traffic, large supplies of wine were imported from France, while the Irish 'out of gratitude' (non ingrata) gave hides and skins in exchange. ${ }^{4}$ That there was commercial inte1course with Chester and also with the towns round the Bristol Channel may be seen from the names of the citizens of Dublin in the year I200: Thorkaill, Swein Ivor from Cardiff; Turstinus and Ulf from Bristol; Godafridus and Ricardus from Swansea; Thurgot from Haverfordwest and Harold from Monmouth. ${ }^{5}$ About II 70 two ships sailing from England "laden with English cloths and a great store of goods" were attacked and plundered near Dublin by a Norseman, Swein, son of Asleif ; and some years later vessels from Britain carrying corn and wine were seized in Wexford harbour by the English invaders. ${ }^{6}$

The historical evidence is amply borne out by the existence of such old Norse loan-words in Irish as mangaire (O.N. mangari, a ' trader '), marg (O.N. mörk, a ' mark '), margadh,

${ }^{1}$ Keating: History of Iveland, III., p. 27 r. (Ed. Dinneen). Keating probably derived his information from Giraldus Cambrensis: Topographia Hibernica, D. III., ch. IIII.

Expugnatio Hibernica, I., ch. XVIII.

'De Vita S. Wulstani, II., 20.

(See Cunningham: Growth of English Industry and Commerce, I., p. 86.)

4 Giraldus Cambrensis: Topographia Hibernica, I., ch. VI.

B A. Bugge: Contributions to the History of the Norsemen in Ireland, Part IIf.

- Giraldus Cambrensis : Expugratio Hibernica, I, ch. III. 
(O.N. markathr, a 'market'), and penning (O.N. penningr, a 'penny'), and also by certain archæological discoveries. In Scandinavia coins of King Sithric Silken-Beard have been found, ${ }^{1}$ while four sets of bronze scales and some weights richly decorated in enamel and gold have been dug up in Ireland (Bangor, Co. Down). ${ }^{2}$ To the same period (early ninth century) also belong the scales and weights which were discovered in the great hoard at Islandbridge, near Kilmainham in $1866 .^{3}$ With such strong evidence of the influence exerted by the Vikings on the expansion of Irish trade it is not surprising to find that even as late as the seventeenth century the greater part of the merchants of Dublin traced their descent to Olaf Cuaran and the Dublin Norsemen."

1 A. Bugge: Vesterlandenes Indflydelse paa Nordboernesi Vikingetiden, pp. 300-304.

2 G. Coffey, op. cit., p. 9 I.

3 Ib., p. 89.

- Duald Mac Firbis: On the Fomorians and the Norsemen (ed. A. Bugge), p. Ir. 


\section{CHAPTER V. \\ SHIPBUILDING AND SEAFARING.}

THE almost complete absence of any allusion to Irish ships ${ }^{1}$ during the eighth and ninth centuries shows that at this time the Irish had no warships to drive back the powerful naval forces of the Vikings. Meeting with no opposition on sea the invaders were able to anchor their fleets in the large harbours, and afterwards to occupy certain important positions along the coasts. In this connection it is interesting to note that the Irish word longphort (a 'shipstead '; later, ' a camp') is used for the first time in the Annals of Ulster with reference to the Norse encampments at Dublin and Linn-Duachaill (840); hence it has been concluded that the early Norse long-phorts were not exactly fortified camps, but ' ships drawn up and protected on the landside, probably by a stockaded earthwork.' 2

The Annalists tell how, when the Vikings were expelled from Dublin in 902, they fled across the sea to England, leaving large numbers of their ships behind them. It was probably the capture of these vessels that impressed upon the Irish the advantages of this new method of warfare, for they now began to build ships and to prepare to meet

1 Only one reference is to be found in the Annals. See Annals of the Four Masters, A.D. 728.

"Eoin MacNeill : "The Norse Kingdom of the Hebrides" (Scottish Review., Vol. XXXIX., pp. 254-276). 
the Vikings in their own element." In 913 a " new fleet," manned by Ulstermen, attacked the Norsemen off the coast of Man but was defeated. 2 Another Ulster fleet commanded by Mruirchertach mac Neill, King of Aileach, sailed to the Hebrides in 939 and carried off much spoil and booty. ${ }^{\mathbf{3}}$ Moreover, the Irish seem to have imitated the Scandinavian practice of "drawing" or carrying their light vessels over land to the lakes and rivers in the interior of the island. Mention is made of Dombnall, son of Muirchertach, who " took the boats from the river Bann on to Lough Neagh, and over the river Blackwater upon Lough Erne, and afterwards upon Lough Uachtair."

The men of Munster also had their navy, which they organised according to Norse methods ${ }^{5}$ by compelling each district in the different counties to contribute ten ships to it. Thus by the middle of the tenth century they were able to put a formidable fleet to sea. When Cellachan of Cashel (d. 954) was captured by the Vikings and brought to Dublin,

${ }^{1}$ It is interesting to recall that a new development in shipbuilding, probably due to the same causes, was taking place in England about the same time. The Anglo-Saxon Chronicle first mentions a naval encounter with Vikings under the year 875 , and some twenty years later describes the long ships, "shaped neitlier like the Frisian nor the Danish," which Alfred had commanded to be built to oppose the oescs, or Danish ships.

2 Annals of Ulster, A.D. 912.

3 Annals of the Four Masters, A.D. 939.

- Annals of the Four Masters, A.D. 953 (=955). Annals of Ulster, A.D. 963 .

To this entry the annalist adds the following note: "Quod non factum est ab antiquis temporibus."

Cf. Three Fragments of Annals (A.D. 873) : "Bairith (O.N. Barthr), drew many ships from the sea westwards to Lough Ree. ..."

- Ancient Norway was divided by Haakon into districts (Skipreithur) each of which had in wartime to equip and man a warship: the number of these districts was fixed by law. Gulathingslog, ro. Cf. The Victorious Career of Cellachan of Cashel, p. I5I, $\mathrm{n}$; etc. Cf. The Saga of Haakon the Good (Heimskr.), ch. 2 I. 
he sent messengers to the Munstermen bidding them to defend their territory: " and afterwards," he said, "go to the chieftains of my fleet and bring them with you to Sruth na Maeile (Mull of Cantyre), and if I am carried away from Ireland, let the men of Munster take their ships and follow me." 1 The chronicle goes on to give a vivid description of the great naval battle which followed: the Vikings under the leadership of Sihtric, a prince from Dublin, took up their position in the Bay of Dundalk, where the "barques and swift ships of the men of Munster" met them. The Irish ships were arranged according to the territories they represented: those of Corcolaigdi and $\mathrm{Ui}$ Echach (Co. Cork) were placed farthest south; next came the fleets of Corcoduibne and Ciarraige (Co. Kerry), and lastly those of Clare. When the Munstermen saw Cellachan, who had been bound and fettered to the mast by Sihtric's orders, they made gallant attempts to release him; some of them leaped upon " the rowbenches and strong oars of the mighty ships" of the Norsemen, while others threw tough ropes of hemp across the prows to prevent them from escaping. Failbhe, King of Corcoduibne, brought his ship alongside Sihtric's, and with his sword succeeded in cutting the ropes and fetters that were round the King, but was himself slain immediately afterwards. The battle ended in victory for the Irish : the Norsemen were forced to leave the harbour with all their ships, but " they carried neither King nor chieftain with them."2

The War of the Gaedhil with the Gaill records still more victories for the Munster fleet during the reign of Brian Borumha. In 984 he assembled "a great marine fleet" on Lough Derg and took three hundred boats up the

${ }^{1}$ The Victorious Career of Cellachan of Cashel, pp. 29, 86.

I Ib., pp. 89-I02. 
Shannon to Lough Ree 1 and again in IOOI sailed with his fleet to Athlone. But the greatest triumph of all was in 1005, when Brian, then at the height of his power, "sent forth a naval expedition composed of the foreigners of Dublin and Waterford and the Ui Ceinnselaigh (i.e., the men of Wexford) and almost all the men of Erin, such of them as were fit to go to sea; and they levied royal tribute from the Saxons and the Britons and from the men of Lennox in Scotland and the inhabitants of Argyle."s

The Anglo-Saxon Chronicle records the names of a number of Frisian sailors who fought with the English in a naval battle against the Vikings (A. an. 897). In the same way the Irish ships must have been manned to a large extent by Norse mercenaries or by the Gaill-Gaedhil, for practically all the shipping terms introduced into Irish in the tenth and eleventh centuries are of Norse origin." This is evident from the following list:-

Mid. Ir. abor, abur: O.N. hábora, ' an oar hole.'

Accaire :

Accarsoid :

Achtuaim : athbha:
O.N. akkeri, ' an anchor.'

O.N. akkerissaeti, 'a harbour for ships.'

O.N. aktaumr, ' a brace.' phonetic form (af, av) of O.N. höfuth, ' head ' of a ship.

'War of the Gadhil with the Gaill, p. Iog.

I Ib., p. 133.

s $I b .$, p. 137 .

- See A. Bugge: Norse Loan-reords in Irish (Miscellany Presented to Kuno Meyer, p. 29I fi.).

W. A. Craigie: Oldnordiske Ord $i$ de Gaeliske Sprog (Avkiv fór Nordisk Filologi, X., I894).

C. Marstrander: Pidrag til det Norske Sprogs Histnrie i Irland.

K. Meyer: Revue Celtique, X., pp. 367-9.

$\begin{array}{ll}\text { " } & \text { XI., pp. } 493-5 . \\ & \text { ". }\end{array}$



Allsad:
O.N. halsu, 'to slacken a sail.'
As :
O.N. ass, "the pole to which the lower end of a sail was fastened during a fair wind.'
bat, bad:
O.N. bátr, 'a boat.'
birling :
O.N. byrthingr, ' a transport vessel,' 'a merchant ship..'
carb :
O.N. karfi, ' a ship.'
chairr:
O.N. knörr, ' a merchant ship.'
laideng :
O.N. leithangr, ' naval forces.'
lipting:
lunnta, lunn (in
O.N. lypting, ' a taffrail.'

\section{reania) :}
scib :
tile :
O.N. hlunnr, ' the handle of an oar.' O.N. skip, ' a ship,' whence also are derived sciobaire, 'a sailor' and scipad and sgiobadh, 'to make ready for sailing.'

Thusdais (? teldass) : O.N. tjaldáss, 'the horizontal topuicing, a word used for 'a fleet': O.N. Vikingr, 'one who haunts a bay or creek.'

uiginnecht, piracy :

1 Marstrander (op. cit., p. 2I) suggests that the word is connected with the O.N. dialectal form berling, " a little stick or beam under the shallows in a boat." 


\section{LINGUISTIC INFLUENCES.}

\section{(a) Loan-words from Old Norse in Irish.}

THE large number of loan-words from Old Norse which occur in Old and Middle Irish indicate clearly the extent and character of Scandinavian influence in Ireland. They are therefore interesting from an historical point of view, for they confirm, and sometimes supplement, the evidence of Irish and Icelandic sources, that the relations existing between the two peoples were largely of a friendly character.

As the subject has already been fully dealt with by Celtic scholars, ${ }^{1}$ only the more important loan words are given here :-

\section{DREss ${ }^{2}$ AND ARMour.}

O.Ir. at-cluic, also clocc-att ' a helmet.' att $=$ O.N. hattr, ' a hat,' while cluic = M. Ir. clocenn, 'a head'

Mr. Ir. allsmann; O.N. halsmen, 'a necklace.'

M. Ir. boga ; O.N. bogi, 'a bow.'

M. Ir. bossan; O.N. puss, 'a small bag or purse hanging from the belt.'

M. Ir. cnapp; O.N. knappr, ' a button.'

1 Cf. the list of authorities referred to ante, pp. 38,39 .

2 The Norsemen sometimes adopted Irish fashions in their dress. The great Viking Magnus, who was killed in Ireland in A.D. rro3, was usually called "barelegs " (O.N. berfaettr) because he always wore the Irish kilts; and his son, Harold Gilli, who could speak Irish better than Norse, "much wore the Irish raiment, being short-clad and light-clad." It was probably from his Irish cuaran, or shoes of skin that Olaf Sihtricsson, the famous King of Dublin received his nickname. 
M. Ir. elta ;

M. Ir. mattal ;

M. Ir. mergge ;

M. Ir. sceld ;

O. Ir. scot, lin scoit;

M. Ir. starga ;

M. Ir. bailc;

M. Ir. fuindeog;

M. Ir. garda ;

M. Ir. halla ;

M. Ir. sparr;

M. Ir. stoll ;
O.N. hjalt, 'a hilt' (of a sword).

O.N. möttull, ' a cloak.'

O.N. merki, ' a flag' or 'banner.'

O.N. sköjldr, ' a shield.'

O.N. skaut, ' a cloth,' or 'sheet.'

O.N. targa, 'a shield.'

\section{HOUSEBUILDING.}
O.N. bailkr, 'a beam.'
O.N. vindauga, ' a window.'
O.N. garthr, ' a garden.'
O.N. höll, ' a hall.'
O.N. sparri, ' a rafter.'
O.N. stoll, ' a stool.'

\section{III.}

Other interesting loan words are :-

O. Ir. armand,
armann;
O.N. armathr, 'an officer.'

M. Ir. callaive;

O.N. kallari, ' a herald.'

M. Ir. gunnfann ;

O.N. gunnfáni, 'a battle standard.'

O. Ir. evell ; M. Ir.

\section{iarla;}

M. Ir. lagmainn ; 1 .

O.N. jarl, ' an earl.'

O.N. lögmenn, plural of lögmathr, 'a lawman.'

M. Ir. Pers ;

O.N. berserkr.

M. Ir. sraid ;

O.N. straeti, ' a street.'

M. Ir. sreang ;

O.N. strengr, ' a string.'

M. Ir. traill ;

O.N. thraell, 'a slave.'

M. Ir. trosg ;

O.N. thorskr, ' codfish.'

O. Ir. ustaing ;

${ }^{1}$ In the Annals of the Four Masters (A.D. 960), lagmainn is the name given to certain chieftains from the Hebrides who plundered the southern and eastern coasts of Ireland.

${ }^{2}$ The word occurs only once in Irish : cf. The Victorious Carser of Cellachan of Cashel, p. I 40. 
Certain old Norse words and phrases which are to be found in Irish texts also go to show the familiarity of the Irish with the Norse language. They may be mentioned here, although they are not loan-words, but rather attempts on the part of the Irish authors to reproduce the speech of the foreigners:-

cing. ${ }^{3}$

O.N. konungr, or possibly

A.S. cyning.

conung (Three Fragments of

Annals, pp. I26, I94, 228). O.N. konungr, ' a king.'

"Faras Domnall?" (War of

the Gaedhil with the Gaill ;

p. I74).

"Hiar es Dominall?"

"Where is Domhnall?"

"Sund a sniding," was the reply.

O. Ir, silnd, " here,"

O.N. nithingr, "here, rascal."

fiut (Book of Leinster, I72,
a, 7).
O.N. hvitr, ' white.'

Infuit, a personal name;

War of the Gaedhil with

the Gaill, p. 78.

O.N. hvitr, ' white.'

1 The IVar of the Gaedhil with the Gaill, p. 203, says that when the Norsemen were fleeing after the battle of Clontarf, Earl Broder, accompanied by two warriors, passed by the tent in which King Brian was. One of these men, who had been in Brian's service, saw the Fing and cried " Cing, Cing" (This is the King). "No, no, aclut prist, prist" said Broder (No, no, it is a priest, said Broder). 
litill (ibid., p. 84).

O.N. litill, ' little.'

mikle (Three Fragments of

Annals, p. 176).

O.N. mikill, ' much.'

nui, nui (ibid, p. 164).1

O.N. knice, from knýja, 'to advance.'

roth. ${ }^{2}$

O.N. rauthr, 'red.'

\section{(b) Gaelic Words in Old Norse Literature. ${ }^{3}$}

Considering the close connection between Ireland and Iceland, especially in the tenth and eleventh centuries, it is surprising that so few Gaelic words found their way into Old Norse literature. The only Norse words that can be said, with any certainty, to be derived from Irish, are the following :-

bjannak (Ynglingasaga,

Heimskringla, ch. 2) : Ir. bennacht, ' a blessing.' evg (Orkneyinga Saga, ch. Ir3) Ir. airghe, (I) ' a herd of cattle.'

(2) 'grazing land.'

1 These annals state that on one occasion (A.D. 869) Cennedigh of Leix, a brave Irish chieftain, was pursued by the Norsemen, who "blew their trumpets and raised angry barbarous shouts, many of them crying " nui, nui.'"

${ }^{2}$ Marstrander (op. cit, p. 156 ) suggests, however, that roth may be an archaic form of the Irish ruadh, 'red.'

${ }^{3}$ Cf. W. A. Craigie: Gaelic Words and Names in the Sagas and Landnámabók. (Zeitschrift für Celtische Philolngie, Band I., pp. 439-454).

A. Bugge: Vesterlandenes Indflydelse paa Nordboemes $i$ Vikinge. tiden, ch. 9. See especially pp. 358-359. 


\section{gelt ;1}

Ir. geilt, 'a madman.'

varth at gialti, to become mad

with fear. Cf. Eyrbyggia

Saga, ch. 18.

ingian;

Ir. inghean, ' a girl.'

kapall (Fornmanna Sögur II.,

p. 23I);

Ir. capall, ' a horse.'

kesja ;

Ir. ceis, 'a spear.'

korki (Snorres Edda, II., 493); Ir. coirce, ' oats.'

kross ;

kuaran ;
Ir. cros, ' a cross.'

Ir. cuaran, 'a shoe' (made of skin).

1 There is an interesting account of the gelt in the Old Norse Konungs Skuggsjá (Speculum Regale) :

"It happens that when two hosts meet and are arranged in battlearray, and when the battle-cry is raised loudly on both sides, cowardly men run wild and lose their wits from the dread and fear which seize them. And they run into a wood away from other men, and live there like beasts and shun the meeting of men like wild beasts. And it is said of these men then when they have lived in the woods in that condition for twenty years, that feathers grew on their bodies like birds, whereby their bodies are protected against frost and cold. ..."

Cf. Kuno Meyer: On the Irish Mirabilia in the Old Norse "Speculum Regale" (Eviu, Vol. IV., pp. II-I2).

This bears a striking rescmblance to a certain passage in the mediaeval romance Cath Muighe Rath (Battle of Moy Rath, p. 232. Ed. by O'Donovan). It may also be compared with another romance, which probably dates from the same period, viz., Buile Suibhne. (The Madness of Suibhne, ed. by J. G. O'Keefe for the Irish Texts Society). Cf. also Hávamál (ed. Gering), str. 129, etc. 
kuthi; 1

male diarik;

minnthak;3

rig (in Rigsmál);

tarfr (Eyrbyggia Saga, ch. 63,
? Ir. cuthach, 'fierce.'

Ir. mallacht duit, a rig, 'a curse upon you, O king.' Ir. mintach, ' made of meal.'

Ir. $r i(g)$, ' a king.'

Ir. tarbh, ' a bull.'

\section{(c) Irish Influence on Icelandic Place- nomenclature.}

A number of the place-names mentioncd in the Landnámabók $k^{4}$ contain a Gaelic element which, with one or two exceptions, is present in the form of a personal name. Among these Icelandic place-names we may note the following :-

Bekkanstathir;

(I) Branslackr, (also Brjamslackr);
Personal Name.

Ir. Beccán.

Ir. (I) Bran, (2) Brian.

1 Vilbald, a descendant of Kjarval, King of Ossory, had a ship called Kuthi, cf. Landnámabók, IV., ch. Ir. Todd (War of the Gaedhil with the Gaill, p. 299, n.) suggests Ir. Cuthach.

2 According to Jáns Saga hins Helga, ch. I4 (Biskupa Sögur I., Kaupmannahófn, 1858) King Magnus Barelegs sent an Icelander with other hostages to King Myrkjartan of Connacht. When they arrived there, one of the Norsemen addressed the King in these words: "Male diarik," to which the King replied "Olgeira ragall," i.e., Ir., olc aer adh ra gall, (it is a bad thing to be cursed by a Norseman.)

3 minnthak was the name given by Hjörleif's Irish thralls to the mixture of meal and butter which they compounded while on board ship on their way to Iceland. They said it was good for quenching thirst. Cf. Landnámabok, I., ch. 6.

- Cf. Whitley Stokes, op. cit., pp. I86 I9t. 
Dufansdalir;

Dufthaksholt:

Kalmansa ;

Personal Name.

Ir. Dubhan.

Ir. Dubhthach.

also Dutthakskor; etc.

also Kalmanstunga.

Kjallakshöll, Kjallaksslathir; Ir. Ceallach.

Kjaransvik :

Kylansholar:

(I) Lunansholt or

(2) Lumansholt;

Minnthakseyr:

Papýli, Papey:

Patrekstjörthr:
Ir. Ciarain.

Ir. Culen (Marstrander).

Ir. (I) Lon-án

(2) Lommán.

Ir. mintach, 'made of meal.'

Ir. ' papa,' ' an anchorite.'

Ir. personal name Patraic. 


\section{THE VIKINGS AND THE CELTIC CHURCH.}

BEYOND a few ineagre allusions the Irish Annals throw no light on the progress of Christianity anıong the "foreigners" in Ireland during the ninth century. Fortunately, however, the Icelandic Sagas and the Landnamabo $k$ have preserved some interesting details concerning a small number of the Norse settlers in Iceland, who had previously come under the influence of Christianity in Ireland and in the Western Islands of Scotland. As far as we can gather from these sources the new faith seems at first to have made but little headway ; heathenism retained a strong hold on the majority of the Norse people, and there can be little doubt that this form of religion was extensively practised in Ireland during the Viking age. Evidence of this is to be found in The War of the Gaedhil with the Gaill, which describes how Authr, wife of Turgéis, sat on the high altar of the church in Clonmacnois, and gave audiences as a prophetess. ${ }^{1}$ In this instance the high altar would seem to have corresponded to the seithr hjallr or platform which it was customary to erect in Icelandic houses when a völva or prophetess was called in to foretell the future. ${ }^{2}$ Some writers ${ }^{3}$ also point

IWar of the Gaedhil with the Gaill, p. 13.

Cf. also Three Fragments of Annals, p. I 46 : "In a battle fought between the Irish and the Norsemen the latter were driven to a small place surrounded by a wall. The druid Hona went up on the wall, and with his mouth open began to pray to the gods and to exercise his magic; he ordered the people to worship the gods. ...."

2 Cf. Thorfinssaga Karlsefuis, cli. 3; Valusdaela Saga, ch. Io ; Thátry af Normagesti, ch. I I ; Hrólfs Saga. Kraka, ch. 3; etc.

s e.g., C. Haliday: The Scandinavian Kingdom of Dublin, $\mathrm{P}$ I 2 fi. Margaret Stokes, op. cit., pp. 96-98. 
to the numerous raids on churches and religious houses as a proof of the Vikings' hostility to Christianity, but these attacks were much more likely to have originated in the amount of treasure which the raiders knew to be stored in these places. It is rather in this light, too, that we must regard 'Turgéis' expulsion of the abbot Farannan from Armagh (in 839), and his subsequent usurpation of the abbacy, ${ }^{1}$ than as an attempt to stamp out Christianity and establish heathenism in its stead.

Yet, at the same time, the Norsemen must have come into close contact with the religion of the "White Christ" through their intercourse with the Irish. Indeed, an entry in the Annals of Ulster (A.D. 872), referring to the death of Ivarr the Boneless, implies that this famous Viking died a Christian. ${ }^{2}$ The records are silent on this point with regard to Olaf the White, although he was related by marriage to Ketill Flatnose, a famous chief in the Hebrides, all of whose family, with the exception of his son, Björn the Easterner, adopted Christianity. Olaf's wife, Authr, daughter of Ketill, was one of the most zealous of these early Norse converts: "She used to pray at Crossknolls, where she had crosses erected, because she was baptized, and was a good Christian." Before her death she gave orders that she was to be buried on the seashore, between high and low water-mark, because she did not wish to lie in unconsecrated ground. The Landnamabok also says that for some time after her death her kinsfolk reverenced these knolls, but in course of time their faith became corrupt, and in the same

1 Cf. War of the Gaedhil with the Gaill, p. 8.

2 The expression used is quievit in Christo and occurs only in $M S$. A. As neither MS. $B$ nor any of the other annals mention Ivárr's conversion it may be that the scribe of the former has unintentionally slipped into using a formula which was customary in recording the death of a Christian. 
place they built a temple and offered up sacrifices. ${ }^{1}$ IVe hear, too, of Orlygr the Old, who had been fostered by Bishop Patrick in the Hebrides. When he was setting out for Iceland the Bishop gave him " wood for building a church, a plenarium, an iron penny and some consecrated earth to be put under the corner pillars," and asked him to dedicate the church to St. Columba. On the voyage a great storm arose. Orlygr prayed to St. Patrick that he might reach Iceland in safety, promising, as a thanksgiving, to call the place in which he should land by the saint's name. ${ }^{3}$ Mention is also made of several other Christiars from the Britislı Isles : Jörundr, Helgi Bjóla ; ${ }^{3}$ Thorkellson of Svarkell from Caithness-" who prayed before the cross, ever good to old men, ever good to young men;" 4 Ásólf, ${ }^{5}$ Ketill-grandson of Ketill Flatnose-who was surnamed hinn fiflski ("the foolish ') because he adhered to Christianity. ${ }^{\circ}$ A long time after (c. A.D. 997) Thangbrandr the Priest found descendants of Ketill's in Iceland, " all of whom had been Christians from father to son."? Considering the missionary ardour of the Irish at this period it is curious that no priests accompanied these early settlers to Iceland. This may have been due to scepticism as to the sincerity of these converts ; such, at least, is the impression received from the Irish annals and chronicles, in which the Norsemen are almost invariably referred to as 'heathens' and 'pagans.' The result was that the influence of Christianity declined in Iceland ; " some of those who came from west-the-sea remained Christians until the day of

${ }^{1}$ Landnámabók, II., ch. I6.

${ }^{2}$ Landnámabók, I., ch. 12.

${ }^{3} \mathrm{Ib}$., V., ch. 15 .

${ }^{4} \mathrm{Ib}$., I., ch. I3.

Ib., I., ch. I5.

${ }^{6} \mathrm{Ib}$., IV., ch. II.

${ }^{7}$ Njáls Saga, ch tor. 
their death" says the Landnamabo"k, "but their families did not always retain the faith, for some of their sons erected temples and offered sacrifices, and the land was wholly lieathen for nearly one hundred and twenty years." 1

In the transition from heathenism to Christianity opposing beliefs were sometimes held at the same time; the Viking continued to have recourse to Thor even after he had been baptized. Helgi the Lean, son of Eyvindr the Easterner, and Rafarta, daughter of King Cearbhall of Ossory, "was very mixed in his faith; he believed in Christ, but he invoked Thor for seafaring and brave deeds. When he came in sight of Iceland he asked Thor where he should settle down;" and when he had built his house, " he made a large fire near every lake and river, thus sanctifying all the land between. . . . Helgi believed in Christ, and therefore named his house after Him."' 2 We also read that "Örlygr the Old and his family trusted in Columba,"s but whether they abandoned all other belief in the Christian faith and fell into Paganism is not quite clear. Again, in the account of the naval battle between Danes and Norsemen in Carlingford Lough (A.D. 852) the annalist describes how "Lord Horm," leader of the Danish forces, advised his men to "pray fervently" to St. Patrick, "the archbishop and head of the saints of Firin," whose churches and monasteries the Norsemen had plundered and burned. So the Danes put themselves under the protection of the saint: "Let our protector," they cried, "be the holy Patrick and the God who is lord over him also, and let our spoils and our wealth be given to his church." After the battle ambassadors frcm the ard-ri found the Danes seated round a great fire, cooking their food in cauldrons-which

${ }^{1}$ Landnimabók, V., ch. I 5 .

2 Ib., III., ch. 12.

s Ib., I., ch. I 2 . 
were supported on the dead bodies of the Norsemen, while near by was " a trencl full of gold and silver to give to Patrick; for the Danes," adds the chronicler, "were a people with a kind of piety ; they could for a while refrain from meat and from women."

This confusion of the two religions is also illustrated in the crosses, symbols of Christianity, which the Vikings erected in the north of England and in the Isle of Man to the memory of their kinsfolk. On the Gosforth cross in Cumberland a representation of the Crucifixion-obviously influenced by Celtic designs-is found side by side with a figure of the god Vitharr slaying the Wolf, a scene described in Vafthrúthnismál; while on the western side of the cross is portrayed the punishment of Loki. ${ }^{2}$ A fragment of a cross in the same locality shows Thor fishing for the Mithgarthsormr, ${ }^{3}$ a subject which is also treated on a cross slab in Kirk Bride Parish Church, Isle of Man." Among the many other Celtic crosses in Man are four upon which are carved pictures from the story of Sigurthr Fáfnisbani: Sigurthr roasting the dragon's heart on the fire and cooling his fingers in his mouth, his steed Grani and the tree with the talking birds; another figure has been identified with Loki throwing stones at the Otter. ${ }^{5}$ There are besides twenty-six crosses with Runic inscriptions, six of which bring out the Viking connection witl the Celtic Church. On one the Ogam alphabet is scratched, and the same monument bears a Runic inscription which tells us that "Mal Lumkun (Ir. Mael Lomchon) raised this cross

${ }^{1}$ Three Fragments of Annals, pp. I 20-124.

2 Cf. Gylfaginning, chs. 5I, 52.

${ }^{3}$ Hymiskvithw, pass. Cf. II. S. Calverley : The Ancient Crosses at Gosforth, p. 168.

P. M. C. Kermode : Manx Crosses, pp. I80-184.

5 Ib., pp. I 70-I 79 . 
to his foster (mother) Malmuru (Ir. Maelmuire), daughter of Tufgal (Ir. Dubhgall), whom Athisl had to wife." To this the rune writer adds: "It is better to leave a good fosterson than a bad son." 1 Crosses were also erected by Mail Brikti (Ir. Mael Brigde), son of Athakan (Ir. Aedhacan) the smith $;^{2}$ by Thorleifr Hnakki in remembrance of his son Fiak (Ir. Fiacca) $;^{3}$ and by an unknown Norseman to the memory of his wife Murkialu (Ir. Muirgheal). ${ }^{4}$ Another cross-slab commemorates Athmiul (? Ir. Cathmaoil), wife of Truian (i.e., the Pictish name Driian), son of Tufkal, ${ }^{5}$ while still another stone contains a fragment of a prayer to Christ, and the Irish saints, Malaki (Malachy), Bathrik (Patrick), and Athanman (Adamnan). ${ }^{\circ}$

The advance of Christianity during the tenth century may be attributed to a large extent to the prevalence of the practice known as prime-signing or marking with the sign of the cross. According to Eyrbyggja Saga (ch. 50), this was "a common custom among merchants and mercenary soldiers in Christian armies, because those men who were 'prime-signed' could associate with Christians as well as heathens, while retaining that faith which they liked best." Nearly all the Norse kings who reigned in Dublin during this century seem to have accepted Christianity. When Gothfrith plundered Armagh in 9I9 " he spared the church and the houses of prayer, with their company of culdees (ceile-de) and the sick." " We may assume

${ }^{1}$ Ib., pp. 86-95, 195-199.

${ }^{2} I b .$, pp. I $50-153$.

${ }^{3} \mathrm{Ib}$., pp. 203-205.

4 Ib., pp. 209-2I3.

' Ib., p. 169 .

Ib., pp. 212-213.

"Annals of Ulster, A.D. 919. The same source in recording Gothfrith's death (A.D. 933) speaks of him as "the most cruel of the Norsemen." 
that Sihtric Gale, Gothfrith's brother (or cousin) was also a Christian, since he formed a friendly alliance with Aethelstan, who gave him his sister in marriage. ${ }^{1}$ In 943 Olaf Cuaran was baptized, and in the same year Rögnvaldr, another Norse prince, was confirmed. ${ }^{2}$ After the battle of Tara (980) Olaf went on pilgrimage to Iona, where he died " after penance and a good life." 3 His daughter and grandson were called by distinctively Irish Christian names -Maelmuire (servant of Mary), and Gilla Ciarain ${ }^{5}$ (servant of St. Ciaran). We may also note the name Gilla-Padraig which occurs in the royal family of Waterford ${ }^{6}$ and the half-Irish name of a priest in Clonmacnois, Connmhach Ua Tomrair, who must have been of Norse extraction. ${ }^{7}$

But all traces of heathenism in Ireland had not disappeared by the end of the tenth century. An interesting relic was Thor's ring (Ir. fail Tomhair) which was carried off from Dublin by King Maelsechnaill II. in $994 .^{8}$ This must have been the dóm-hringr, so frequently alluded to in Icelandic literature. It was a ring of silver or gold, about twenty ounces in weight, which lay upon an altar in the tenple, except during ceremonies, when it was worn on the priest's arm.9 Upon this ring oaths were usually sworn. ${ }^{10}$ That it was connected with the worship of Thor is clear from a passage in the Landnamabók describing a place called

1 Anglo-Saxon Chronicle, MS.D., A.D. 925.

IIb., MSS. A., 942, D. 943.

3 Annals of the Four Masters, A.D. 979.

4 Ib., A.D. 1021.

Was of the Gaedhil with the Gaill, p. 207.

- Annals of the Four Masters, A.D. 982.

7 Ib., A.D. IOI I.

Ib., A.D. 994 .

${ }^{9}$ Eyrbyggja Saga, chs. 4 and ro; Kjalnesinga Saga, ch. 2 ; ete. 10 Cf. Anglo-Saxon Chronicle, MS.A. Annal, A.D. 876, Kjalnesinga Saga, ch. 2 ; etc. 
Thorsnes in Iceland: "there still stands Thor's stone, on which were broken the backs of those men who were about to be sacrificed, and close by is the domhringr where the men were condemned to death." 1 Even as late as the year A.D. Iooo we hear of Thor's wood (caill Tomair) north of Dublin, which was laid waste by Brian Borumha after the battle of Gleann Mama. ${ }^{2}$

The battle of Clontarf (A.D. IOI4) is frequently represented as a great fight between Pagan and Christian, but this point of view is hardly confirmed by the historical facts. It is true that the Norsemen numbered among their supporters such prominent upholders of heathenism as Sigurthr, earl of Orkney, and Broder-who had been a mass-deacon, but " now worshipped fiends, and was of all men most skilled in sorcery," yet it must be remembered that the Leinstermen, under their king Maelmordha, also formed part of the Norse army on the same occasion. Moreover, both the Norse and Irish accounts of the battle agree that Gormflaith, who had been the wife of Brian Borumha, inspired by hatred of Brian, was mainly responsible for the renewal of hostilities between the two peoples. Her son, Sihtric Silken Beard, who was most active in mobilising the Norse troops, must have been a Christian, since the coins which were minted in Dublin during his reign are stamped with the sign of the cross. In 1028 he visited Rome, and there is record of another visit some years later. ${ }^{3}$ His death is entered in the Annals under the year I042, in which same year his daughter, a nun in an Irish convent, also died."

It was probably on his return to Dublin from Rome in

'Landnámabók, II., cl. I2.

2 War of the Gaedhi! with the Gaill, pp. 196, 198.

3 Annals of Tigernach, A.D. 1028, In36.

Ib., A.D. IO42. 
1036 that Sihtric gave " a place on which to build a clurch of the Blessed 'Trinity," afterwards known as Christchurch Cathedral, and " contributed gold and silver wherewith to build it."'1

The Norsemen would seem to have regarded the Irish Church with no friendly feelings. The first Norse bishop, Dunan or Donatus, was on intimate terms with Lanfranc, and when the next bishop, Patrick, was chosen by the clergy and people of Dublin, he was sent, with a letter professing their " bounden obedience " to Lanfranc for consecration (A.D. I074). ${ }^{2}$ His successors, Donatus (d. I095), Samuel (d. II2I), and Gregory (d. II62) were also consecrated at Canterbury, and acknowledged the supremacy of the archbishop. An interesting letter addressed to the Archbishop of Canterbury by the priests and citizens of Dublin in II2r is still extant: "You know," the letter runs, "that the bishops of Ireland, more especially the Bishop of Armagh, is extremely angry with us because we will not submit to his decrees, and because we always wish to remain under your authority. ${ }^{3}$

Bishoprics were founded at IVaterford and IVexford later than in Dublin. Malcus, the first Bishop of IVaterford, was consecrated at Canterbury, and on his arrival in Waterford in Iog6, he began to build a church, dedicated, like that of Dublin, to the Holy 'Trinity."

Some years later we hear of a Bishop of Limerick, Gilla or Gilbert, who does not seem to have been consecrated in England, but who was in close touch with the Arclibishop

IThe Whole Works of Sir James Ware Concerning Ireland, Vol I., p. 30r. (Ware quotes from the Black Book of Christchurch Cathedral, Dublin.)

$2 I b .$, p. 306.

Ib., pp. 309-3I I.

- Ib., pp. 525-6. 
of Canterbury. ${ }^{1}$ He it was who convoked the synod at Rathbresail, at which it was decided to divide Ireland into dioceses: "there," says Keating, "the sees and dioceses of the bishops of Ireland were regulated; Dublin was excluded, because it was not customary for its bishop to receive consecration except from the Archbishop of Canterbury." 2 Limerick and Waterford were placed under the jurisdiction of the Bishop of Cashel, but this decree seems to have been ignored by the people of Linierick, for they elected their next bishop, Patrick, in the ordinary way and sent him to England for consecration. ${ }^{3}$ It is uncertain whether the Waterford people obeyed, as the records merely mention the names of the succeeding bishops.

A still more important synod was held at Kells in Ir32. There the decision of the previous synod regarding the division of the country into dioceses was ratified, and archbishoprics were established at Dublin, Armagh, Cashel, and Tuam. Henceforth the bishops of Dublin, Limerick, and Waterford were consecrated in Ireland, and this marked the close of the connection between Canterbury and the Celtic Cliurch.

\footnotetext{
1 Ib., p. 504.

Cf. J. MacCafirey : The Black Book of Limerick. Introduction, chs. 5 and 7 .

2 The History of Ireland, by Geoffrey Kẹating (ed. P. S. Diuneen). Vol. III., p. 298.

3 Ware, op. cill, p. 505.
} 
CHAP'ILER VIII.

\section{LITERARY INFLUENCE: THE SAGAS OF ICELAND AND IRELAND.}

I.

THE most interesting branch of early Norse literature is the saga or prose story. Of these there are many varieties but the most distinctive are the following: (I) the Í slendinga Sogur, or stories relating to prominent Icelanders, Konunga Sögur, or stories of Kings, chiefly of Norway; (3) Fornaldar Sögur, or stories about early times. All these are essentially Icelandic in origin; sagas having their origin in Norway are by no means unknown, but they are, as a rule, translated or derived from French and other foreign sources. ${ }^{1}$ In their present form the sagas relating to the history of Iceland date for the most part from the thirteenth century, though some of them were probably committed to writing in the latter part of the twelfth.

The earliest Icelandic document of which we have any record is the original text of the Laws, said to have been written in the year Ir8I. Ari's Islendinga-Bók, containing

1 It has been stated (cf. E. Mogk: Geschichte d.r NorwegischIslandischen Literatur. Strassburg, rg04, p. 830) that many of Saxo's stories came from Norway, where they liad been collected by an Icelander in the twelfth century. There can be no doubt that stories of some kind relating to families and localities-especially stories which accounted, or professed to account for local nameswere current in Norway down to this time. Such stories form the basis of many of the Fornaldar Sögur, but in all probability these had been familiar to Icelanders from the first settlement of the island, or at least during the tenth century. We have no evidence that they ever gained literary form in Norway.

Norske Litteraturs Historie, II., p. 79I.)

(Cf. Irinnur Jónsson : Old 
a short account of the settlement of Iceland with notices of the more important events, and accounts of the succession of lawmen and bishops, was written a few years later, though the form in which it has come down to us is that of an abbreviated text written about the year II30. This work, the foundation of all subsequent historical writing in Iceland, contains some short notices, which apparently had been handed down by tradition, but these stories, usually known as sagas, would seem to have been written down somewhat later. Indeed until the close of the twelfth century the language employed for historical writings in Iceland, as elsewhere, was for the most part Latin.

Though the writing of the sagas did not begin until the latter part of the twelfth century, sagas in some form or other must have been in existence much earlier, carried on from generation to generation by oral tradition. This faculty of reciting sagas was a special characteristic of the Icelanders, by whom it was carefully cultivated. In the preface to his Historia Danica Saxo acknowledges his indebtedness to the "men of Thule," who " account it a delight to learn and to consign to remembrance the history of all nations, deeming it as great a glory to set forth the excellence of others as to display their own. Their stores, which are stocked with attestations of historical events, I have examined somewhat closely and have woven together no small portion of the present work by following their narrative." 1

That the art of storytelling did not decline in Iceland even after the majority of the sagas were written down is

${ }^{1}$ The First Nine Books of the Danish History of Saxo Grammaticus. Translated by Oliver EIton (ed. by F. York Powell, p. 5). It is not clear whether Saxo had Icelandic manuscripts before him, but his words leare no doubt that he was aware of the fact that stories had beell carried on by oral tradition. 
attested by Sturlunga Saga. Here we are told that when Sturla visited King Magnus' court at Bergen in I263 the king received him coldly, but afterwards allowed him to accompany the royal party on a voyage to the south of Norway. In the evening one of the sailors asked if there was anyone among them who could tell stories, but he received no answer. He turned to Sturla, "Sturla, the Icelander, will you entertain us ?" "Willingly," said Sturla. Then he related the story of Huld ${ }^{\mathbf{1}}$ better and with much more detail than any of those present had ever heard it told before. Then many men made their way to the deck so as to hear as clearly as possible, and there was a great crowd there. The queen asked: "What is that crowd on the deck ?" A man answered, "Men who are listening to the tale the Icelander is telling." "What story is that ?" she asked. "It is about a great giantess ; it is a good story and well told." On the following day the queen sent for Sturla and asked him to come and bring with him the saga of the giantess. ${ }^{2}$ So Sturla went aft to the quarterdeck and told the story over again. When he had finished, the queen and many of the listeners thanked him and took him to be a learned and wise man. ${ }^{3}$

A much earlier reference to the recitation, and indeed the composition of sagas is found in Thorgils Saga ok Haflitha, in which there is an account of a wedding-feast at Reykholar in III9:

"There was fun and merriment and great festivity, and

1 This was probably something in the nature of a fairy-tale like tlie Huldre-eventyr of modern Norway. We may refer to the story of the witch Huldr given in Ynglinga Saga (ch. I6), and to the supernatural being Holda or Holle in German folk-lore.

2 "hafa meth sér trollkonu-söguna." From these words Finuur Jónsson (op. cit., II., p. 792) concludes that Stu1la possessed a written copy of the saga.

${ }^{3}$ Sturlunga Saga, II., pp. 270-27I. 
all kinds of amusements, such as dancing, wrestling and story-telling. . . H Hrólfr of Skalmarnes told a story about Hrongvithr the Viking, and Olaf 'the sailor's king,' and about the rifling of the barrow of 'Thrainn the berserkr, and about Hrómundr Gripsson, and he included many verses in his story. King Sverrir used to be entertained with this story, and he declared that fictitious stories like these were the most entertaining of any ; and yet there are men who can trace their ancestry to Hromundr Gripsson. Hrollfr had put this saga together. Ingimundr the priest told the story of Ormr, the poet of Barrey and included many verses in it, besides a good poem which Ingimundr had composed, therefore many learned men regard this saga as true." 1

The former of these stories is the Hrómundra Saga which belongs to the class commonly called Fornaldar Sögur.?

Still further back in the reign of Harald Hardradith (1047I066) we have a most important allusion to the art of storytelling. According to the saga ${ }^{3}$ a young Icelander came one summer to King Harald seeking his protection. The king received him into his court on the understanding that he should entertain the household during the winter. He soon became very popular, and received gifts from members of the household and from the king himself. Just before Christmas the king noticed that the Icelander seemed dejected, and he asked the reason. The Icelander replied that it was because of his ' uncertain temper.'

"That is not so," said the king. . . ." I think your stock of sagas must be exhausted, because you have entertained us all through the winter, whenever you were called upon

'Thorgil's Saga ok Haflitha (Sturlunga Saga, Vol. I., p. I9).

2Fornaldar Sögur, Vol. II., p. 323.

${ }^{3}$ Havall's Hardrada Saga, ch. 9 ? (Fommanna Sïgur, VI., pp. $35+-356)$. 
to do so: Now you are worried because your sagas have come to an end at Christmas time, and you do not wish to tell the same over again."

"You have guessed rightly," said the Icelander. "I know only one more saga, but I dare not tell it here, because it is the story of your adventures abroad."

"That is the saga I partice orly want to hear," said the king, and he asked the Icelander to begin it on Christmas Day and tell a part of it every day. During the Christmas season there was a good deal of discussion about the entertainment. Some said it was presumption on the part of the Icelander to tell the saga and they wondered how the king would like it ; others thought it was well told, but others again thought less of it. When the saga was finished, the king, who had listened attentively throughout, turned to the storyteller and said: "Are you not curious to know, Icelander, how I like the saga?"

"I am afraid to ask," replied the storyteller.

The king said: "I think you have told it very well. Where did you get the material for it, and who taught it to you?"

The Icelander answered: "When in Iceland I used to go every summer to the Thing, and each summer I learned a portion of the saga from Halldór Snorrason."

"Then it is not surprising that you know it so well, since you have learned it from hin," said the king.

We may in fact see the origin of the Íslendinga Sögur in certain passages of the sagas themselves. In Fostbroethra Saga, for instance, the story is told of an Icelander named Thormóthr, who went to Greenland in order to avenge the death of bis foster-brother Thorgeirr. On one occasion he fell asleep in his booth, and when he awoke some time later he found, to his surprise, that the place was quite deserted. Then his servant Egrill "the foolish" came to lim and 
said: "You are too far off from a great entertainment." Thormóthr asked: "Where have you come from and what is the entertainment?"

Egill replied: "I have been to 'Thorgrimr Einarsson's booth and most of the people who are attending the Thing are there now."

Thormóthr asked: "What form of amusement have they ?"

Egill answered: "Thorgrimr is telling a saga."

"About whom is the saga?" asked Thormóthr.

"That I do not know clearly," replied Egill, " but I know that he tells it well and in an interesting manner. He is sitting on a chair outside his booth and the people are all around him listening to the saga."

Thormóthr said: "But you must know the name of some man who is mentioned in the saga, especially since you think it so entertaining."

Egill replied : "A certain Thorgeirr was a great hero in the saga, and I think that Thorgrimr himself must have had some connection with it, and played a brave part in it, as is most likely. I wish you would go there and listen to the entertainment."' 1

Then Thormóthr and Egill went to Thorgrimr's booth and stood close by listening to the saga, but they could not hear it very distinctly. Thormóthr had, however, understood from Egill's remarks that this was the same Thorgrimr who had slain his foster-brother and was now recounting his exploits for the amusement of the crowd. More famous is the scene in Njáls Saga where Gunnar Lambi's son, who has just arrived at Earl Sigurthr's palace in the Orkneys is called upon to tell the story of the burning of Njáll's homestead. 
"The men were so pleased that King Sigtryggr [of Dublin] sat on a high seat in the middle, but on either side of the king sat one of the earls. . . Now King Sitryggr and Earl Gille wished to hear of these tidings which had happened at the burning, and so, also, what had befallen since.

Then Gunnarr Lambi's son, who had taken part in the burning was got to tell the tale, and a stool was set for him to sit upon.

... Now King Sigtryggr asked : "How did Skarphethinn bear the burning?"

"Well at first for a long time," said Gunnarr, "but still the end of it was that he wept." And so he went on giving an unfair bias to his story, but every now and then he laughed aloud.

Kári (Kjall's friend who was listening outside) could not stand this and he then ran in with his sword drawn ... and smote Gunnarr Lambi's son on the neck with such a smart blow that his head spun off on to the board before the king and the earls.

"... Now Flosi undertook to tell the story of the Burning and he was fair to all, and therefore what he said was believed."1

For the way in which such stories were preserved from generation to generation we may refer to the end of Droplaugarsona Saga (Ljósvetninga): "Thorvaldr (born c. I006) son of Grimr" - - one of the chief actors in the story" had a son called Ingjaldr. His son was named Thorvaldr, and he it was who told the story." 2

The passagee quoted from Njala Saga and Fóstbroethra Saga seem to show that the art of story-telling was already developed at the beginning of the eleventh century. In these

1 Njáls Saga (by G. W. Dasent), clis. 153, 15 t.

${ }^{2}$ Droplaugarsona Saga (Ljosvetuinga Saga), p. I75 (Austfirthinga Sögur, ed. Jakobsen). 
instances, it is truc, we have only the records of cvents given by the actors themselves or by eyewitnesses, and we cannot be certain that such stories had assumed anything like a fixed form. Far more important is the passage from Haralds Saga Hardrada, ${ }^{1}$ for there the story-teller was not an eyewitness, but had obtained the story, or the material for it, from Halldór Snorrason, an Icelandic follower of King Harald. From what is said about the length of the saga, there can be no doubt that it had been worked up in a very elaborate way. For such elaborate secondhand stories we have no other definite evidence, but again, considering the time which the recital is said to have occupied, it would be unwise to conclude that this later form of the art was entirely new.

We have, therefore, clearly to distinguish two stages in the history of the oral saga ; (i) the story as told by someone who had taken part in the events described; (ii) the secondhand story. The story was soon embellished, especially in the second stage, not merely with such devices as the records of conversation, but even by the introduction of imaginary adventures. Indeed we need not assume that even in the first stage the stories were told in strict accordance with fact. Reference may be made, for instance, to the passage quoted above from Njals Saga, where Gunnarr Lambi's son is said to have told the story of the burning unfairly. Even in the Islendinga and Konunga Sögur fiction forms a not inconsiderable element: in the Fornaldar Sögur it is ovbiously much greater.

Yet there is good reason for believing that in the main the Islendinga and Konunga Sögur are historical. This may be seen by the general agreement between the various 
sagas, since the same characters constantly reappear, and there is little inconsistency witl regard to their circunstances or personal traits. Again, the description of houses, ships, weapons, and other articles seems generally to correspond to those known to date from the period to which the stories refer. There is, moreover, one feature which points to a more or less fixed tradition dating from the closing years of the tenth century, namely, the attitude towards those characters who figured prominently in the struggle between Christianity and heathenism. Thus there are indications that the rather unsympathetic representation of Harold Greycloak and his brothers may be dive to the fact that they were Christians. Still more significant is the attitude of the sagas towards Haakon the Bad, whose character seems to undergo a great change-probably a reflection of the change in the popular opinion of Christianity.

Sagas like those of Egill and Kormak relating to the middle or first part of the twelfth century are few in number and usually contain a considerable amount of poetry; in fact, the prose is not infrequently based upon the poetry. Stories dealing with early Icelandic history from A.D. 874 onwards and Norwegian history of the same period are much less full. In general they appear to be trustworthy, but the details are such as might have been preserved by local or family tradition without the special faculty which is characteristic of the sagas.

Of a totally different character are the sagas relating to times before the settlement of Iceland (A.D. 874). Some of these, such as Völsunga Saga and Hervarar Saga, deal with events as far back as the fifth century, and are, to a great extent, paraphrases of poenus, many of which have come down to us. Very frequently, too, whether based on poems or not, the narrative bears the stanup of fiction. ${ }^{1}$

${ }^{1}$ Cf. the references to Hrómundar Saga, pp. 69, 7o, ante. 
Conditions in Iceland were especially favourable to the development of the art of story-telling, owing partly to the isolated position of the country itself and to the difficulties of communication across the wide tracts of land separating the various settlements within it, partly also to the love of travel which characterised its inhabitants. In Icelandic literature the recital of stories is mentioned in connection with public meetings-such as the annual general assembly (Althingi)-and with social gatherings at the "winternights," the chief season for hospitality in Iceland, when travellers had returned from abroad.

The Icelanders were famous, too, for the cultivation of poetry. This art was evidently much practised in Norway in early times, but we hear of hardly any Norwegian poets after Eyvindr (c. 980), whereas in Iceland poetry flourished for a considerable period after this. Icelandic poets were received with favour not only in Norway, but elsewhere, for instance, in England and Ireland. It has been stated that sagas dealing with the early part of the tenth century owe a good deal to poetry, while stories relating to times earlier than the settlement of Iceland are often almost entirely dependent on poetic sources. Moreover, the cultivation of poetry probably contributed very largely to the development of the faculty of story-telling, and the two arts may have been practised by the same person. On this point, however, we have no precise information.

II.

Yet the remarkable fact that this faculty of story-telling was peculiar to the Icelanders alone among the Teutonic peoples still remains to be explained. It can hardly be without significance that the only parallel in Europe for such a form of literature is to be found in Ireland.

From the allusions to this type of composition in old 
Irish literature it would seem to have existed at a very early period; so early, that its very origin is obscure. There is, for example, mention of a king's " company of story tellers" in the eight lines of satirical verse, said to have been composed by the poet Cairbre on Bress, the niggardly king of the Formorians. ${ }^{1}$

Story-telling was one of the many attractions of the great aonachs or fairs which played the same part in the national life of Ireland as the things or popular assemblies in Iceland. From the poem on the ancient fair of Carman preserved in the Book of Ballymote, we can form an idea of the entertainment provided by the professional story-teller:-

"The tales of Fianna of Erin, a never-wearying entertainment: stories of destructions, cattle-preys, courtships, rhapsodies, battle-odes, royal precepts and the truthful instructions of Fithil the sage : the wide precepts of Coirfic and Cormac."'

The Book of Leinster states that the poet who had

1 The poem is preserved in the Book of the Dun Con (twelfth century), but the form of the language in which it is written is considerably earlier than this date; indeed, the meaning of the verses would be quite obscure if we did not possess explanatory glosses.

Cf. D'Arbois de Jubainville: The Irish Mythological Cycle, p. 96 (Best's translation) : also D. Hyde: A Literary History of Ireland, p. 285 .

There is a possible reference to an Irish storytellcr in an inscription on a stone cross at Bridgend (Glamorganshire). The inscription, which is thought to date from the seventli century, runs : $-(C o)$ nbellini possuit hanc crucem pro anima eius Scitlinissi ... Rlys takes scitlivissi to be an Irish word, a compound of viss (Ir. fis. ' knowledge') and scitl (scetlon, scél, a 'story,' 'news') and surmises that scittiviss might mean a 'messenger,' a 'bringer of news,' a 'scout.' (Cf. Celtic Britain, pp. 313-315.) But scitlitiss can also be explained as "one who knows stories." In that case we might infer that storytelling was a profession in Ireland as early as the serenth century; but the reading appears to be too uncertain to justify ns in attaching any great importance to the inscription.

$2 \mathrm{O}$ Curry: Manners and Customs of the Ancient Irish, II., p. 543. 
attained the rank of ollamh was bound to know for recital to kings and chieftains two hundred and fifty tales of prime importance (prím-scéla), and one hundred secondary ones. ${ }^{1}$ The same source gives the names of one hundred and eighty-seven of these tales, the majority of which have not come down to us. These include stories from the three great cycles of legend, viz., that relating to the gods; to Cuchulain and the warriors of the Red Branch, and to Finn and Fianna. A number of stories relating to the kings of Ireland mentioned in this list have an historical basis; while there are others purporting to deal with kings as far back as 1000 B.c., which are no doubt partly imaginary, and were invented to arouse popular interest in the past history of the country.

We know of several stories and poems about kings and chieftains who played a prominent part in the wars against the Vikings. The list in The Book of Leinster mentions only one, The Love of Gormflaith for Niall (i.e., Niall Glundubh (d. 9I9), a summary of which is contained in the mediæval English translation of The Annals of Clonmacnois. In the case of The Victorious Career of Cellachan of Cashel, it is difficult to say whether this was originally an oral narrative committed to writing for the first time in the fifteenth century, or whether it was copied from an older manuscript, now lost. Brian Borumha and his sons are the principal characters in The Leeching of Cian's Leg, a tale preserved in a sixteenth century manuscript. ${ }^{2}$ It is interesting to note here the presence of a

${ }^{1} \mathrm{O}^{\prime}$ Curry: Lectures on the MS. Materials of Irish History, pp. 243, $5^{8} 3$.

2 Printed in Silva Gadelica (ed. Standish O'Grady), Vol. I., pp. 296-305.

Stories of Brian and his sons are still current in the Gaelic-speaking districts of Ireland. (See Zeitschrift für Celtische Philologie, Band I., pp. $477-492$.) They are, however, more likely to be folk tales, in 
strong folk element which would seem to point towards a popular, not a literary origin.

At the close of the tenth century story-telling was in high favour in Ireland, and the professional story-teller was able not only to recite any one of the great historical tales, but to improvise, if the occasion arose. Mac Coisse, the poet attached to the court of Maelsechnaill II., tells in an interesting prose work how his castle at Clartha (Co. Westmeath) was once plundered by the O'Neills of Ulster. He immediately set out for Aileach in order to obtain compensation from the head of the clan, King Domhnall O'Neill (d. 978). On his arrival, he was received with great honour and brought into the king's presence. In response to Domhnall's request for a story, Mac Coisse mentioned the names of a large number of tales including one called The Plunder of the Castle of Maelmilscotach. This was the only one with which the king was unfamiliar, so he asked the storyteller to relate it. In it Mac Coisse described, under the form of an allegory, the plundering of his castle by the king's kinsmen. When he had finished he confessed that he himself was Maelmilscotach ${ }^{1}$, and he begged the king to grant him full restitution of his property. This the king agreed to do, and the grateful poet then recited a poem of eighteen stanzas which he had composed about the king and his family.2

which the deeds of mythical heroes have been transferred to historical people, than sagas transmitted by oral tradition from generation to generation.

1 i.e., "son of the honeyed words," a poet.

2 O'Curry: Manners and Customs of the Ancient Irish, II., pp. I30-I 35 . 


\section{III.}

The resemblance which we have noted between Icelandic and Irish customs seem to justify us in suggesting that they may be due in part to some influence exercised by the one people upon the other. There is in fact a certain amount of evidence which renders such influence probable. We know that Irish poets and storytellers were welcome guests at the court of the Scandinavian kings in Ireland. In an elegy on Mathgamain, Brian's brother, ${ }^{1}$ one of the Munster bards, says he finds it difficult to reproach the foreigners because of his friendship with Dubhcena, Ivarr's son." And during the lifetime of Brian, Mac Liag, Brian's chief poet, and Mac Coisse, poet and storyteller to Maelsechnaill II., visited the court of Sigtryggr and remained there for a whole year. On their departure they gave expression to their feelings of regret in a poetical dialogue :-

Mac Liag: It is time for us to return to our homes,

We have been here a whole year;

Though short to you and me may seem

This our sojourn in Dublin,

Brian of Banba deems it too long

That he listens not to my eloquence. ${ }^{3}$

Another poem of Mac Liag's, in which he addresses the Scandinavians of Dublin as "the descendants of the warriors of Norway," was also composed in Dublin, at the court of 'Olaf of the golden shields,' soon after the battle of Clontarf."

${ }^{2}$ Mathgamain was murdered at the instigation of King Ivarr of Limerick in 976.

${ }^{2}$ Way of the Gaedhil with the Gaill, pp. 98-99.

O'Carry, op. cit., II., p. 128

Ibid., II., p. 125. 
On the other hand Icelandic sources mention at least three skálds who made their way to Ireland during the tenth century: Thorgils Orraskáld, "who was with Olaf Cuaran in Dublin, and Kormak (Ir. Cormac) who fought with Harold Greycloak in Ireland (c. 96I). ${ }^{2}$ In Gumnlaugs Saga Ormstungu (ch. 8) there is a charming account of the poet's reception in Dublin, shortly after Sigtryggr became king (c. 994): Gunnlaug went before the king and said: "I have composed a poem about you, and I would like to get a hearing for it."

The king answered : "No man has yet made a poem about me, and I will certainly listen to yours."

Then Gunnlaug recited his poem in praise of "Cuaran's son," and the king thanked him for it.

Sigtryggr then called his treasurer and asked: "How shall I reward him for this poem ?"

"As you will, lord," replied the treasurer.

"Shall I give him two merchant-ships?" asked the king.

"That is too much," said the treasurer, "other kings give, as rewards for songs, costly gifts, good swords or gold rings."

So the king gave Gunnlaug his own garments of new scarlet cloth, a tunic ornamented with lace, a cloak lined with choice furs, and a gold ring which weighed a mark. Gunnlaug remained for a short time there and then went to the Orkneys.

It is to be noted, too, that among the original settlers in Iceland there were a not inconsiderable number who came from Ireland and the islands off the west coast of Scotland. These included some of the most important

${ }^{2}$ Kormak's Saga, ch. I9. 
families in the country. We may mention especially Authr, widow of Olaf the White, king of Dublin, with her brothers Ketill the Foolish, Björn, Helgi Bjóla and all their families and dependants ; ${ }^{1}$ also Helgi the Lean who had been brought up partly in the Hebrides, partly in Ireland, Jörundr the Christian and Örlygr the Old. ${ }^{2}$ Not a few of these were partly of Irish stock such as Helgi the Lean, Askell Hnokkan and his brother Vilbaldr who were descendants of Cearbhall, king of Ossory (d. 877). ${ }^{3}$ Sometimes we hear of settlers who were of pure Gaelic blood, like Kalman (Ir. Colman) from the Hebrides, ${ }^{4}$ and Erpr, son of a Scottish earl Maeldúin, ${ }^{5}$ and Myrgjol (Ir. Mruirgheal), daughter of Gliomall, an Irish.king. ${ }^{\circ}$

It has been urged $^{7}$ that the persons mentioned in the Landnamabók as coming from Ireland and Scotland form a very small percentage of the whole number of settlers. But we have to remember that by no means all the colonists are mentioned in the records and genealogies. There can be no doubt that a number of slaves and freedmen accompanied the more important settlers to Iceland, and of these probably the great majority were of Celtic blood. Their numbers, too, were being continually reinforced during the tenth century. It is difficult, however, to estimate how many they were, because in the case of thralls Icelandic names were not infrequently substituted for Irish ones. Thus, of the Irish thralls whom Hjörleifr brought to Iceland only one, Dufthakr, had a Gaelic name.

\footnotetext{
1 Cf. Landnámabók, II., ch. I6, etc.

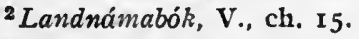

s Ib., IV., ch. II.

Ib., II., ch. I.

sIb., II., ch. 16 .

'Ib., II., ch. I6.

7 Finnur Jónsson, op. cit., II., pp. $187-188$ (n) ; W. A. Craigie : Zeitschrift fur Celtische Philologie, Band I., p. $44 \mathrm{r}$.
} 
Such slaves were not always people of humble origin. Gilli (Ir. Giolla), the slave who killed Thorsteinn, son of Hall ${ }^{1}$ of Side, was a descendant of Cearbhall, king of Ossory. Mention is made elsewhere of Nithbjörg, daughter of the Irish king Biolan (Ir. Beollán) who was carried off from Ireland in a Viking raid ; ${ }^{2}$ also of Melkorka, King Myrkjartan's daughter, who was bought from a slave dealer in Norway. ${ }^{8}$ Icelandic custom did not necessarily prevent the children of slave women from becoming persons of wealth and influence; indeed Ósvifr, son of Nithbjörg and Olaf Pái, son of Melkorka, were among the leading men in Iceland in their time. It is not unreasonable, then, to suppose that by the end of the tenth century Irish blood had found its way into a large number of Icelandic families.

Lastly we may observe that the Irish and Icelandic sagas bear certain resemblances to one another which are at least worthy of attention. In both cases the narrative prose is frequently interspersed with poetry, and in both the use of dialogue is a prominent feature. Nor is the subject matter dissimilar. Indeed it is possible to apply to the Irish stories a classification roughly similar to that which is adopted for the more important of the Icelandic sagas." As far as the "stories of the kings" are concerned, the resemblance is most striking in the case of sagas relating to early times such as Ynglinga Saga. There are Irish stories, too, corresponding to a certain extent to the Islendinga Sögur, though they are comparatively few in

1 "This Gilli was the son of Jathguth, who was the son of Gilli, son of Bjathach (Ir. Blathach), son of King Kjarval of Ireland." (Thorsten's Saga Sithu-Hallssonar, appendix.

Síduhalssonar, Ásmundarson's Ed., pp. 26, 27.

'Draumr Thorsteins

'Landnámabók, II., ch. II.

${ }^{3}$ Cf. p. ante.

Cf. p. 66, ante. 
number, while many of the Fornaldar Sögur may be said to bear a certain resemblance to the Irish epic stories.

The evidence discussed above seems to afford some ground for suspecting that the saga literature of Iceland and Ireland may not be wholly unconnected, and, as we have seen, the conditions of the time, particularly the frequent intercourse between the two countries, were such as to favour the exercise of literary influence by one people upon the other. If so, one can hardly doubt that in this case the influence came to Iceland from Ireland.

We have seen $^{1}$ that the prose saga appears to have developed in Iceland in the course of the tenth century. There are indeed narratives relating both to the settlement of Iceland and to still earlier events in Norway. But these, in so far as they can be regarded as trustworthy traditionsnot embellished by fiction in later times-are quite brief, and not far removed from such local or family traditions as one could find in other parts of the world. The detailed and elaborate type of story which we dealt with in Section I., and which is the distinctive feature of Icelandic literature, can hardly be traced back beyond the end of the tenth century.

The prose stories of Ireland, on the other hand, are without doubt much earlier. Although we have few MSS. of Irish prose dating from a period before the twelfth century, yet it is generally agreed that many of the forms preserved, e.g., in the Yellow Book of Lecan MS. of the Tain Bo Cualnge must be derived from an earlier MS. of not later than the seventh or early eighth century. The oral saga in Ireland is therefore of great antiquity.

It may, of course, be argued that if the prose saga arose spontaneously in Ireland, there is no reason why it should 
not also have arisen independently in Iceland. But the existence of this form of literature in Ireland may be due to special circumstances for which Iceland offers no parallel. The oldest Irish sagas belong to that class of literature known as the heroic epic, a class which among the Teutonic peoples-as indeed among all other European peoplesmakes its first appearance in verse. The exceptional treatment of this subject in Irish is all the more remarkable in view of the fact that among the Celtic peoples the file or professional minstrel occupied a distinguished position in society. It would be strange if the professional minstrel were not primarily concerned with heroic epic poetry in Ireland as in other countries, since in the times to which our records refer the recitation of the heroic prose epics was one of the chief functions of the file.

On the other hand, we know nothing of the ancient forms of Irish poetry. The earliest poems that have come down to us have a metrical form which is not native. Earlier than these-in the fifth and sixth centuries-there is evidence for the cultivation of "rhetorics," or metrical prose, but this too appears to be of foreign origin. ${ }^{1}$ The unique feature in Irish literature, namely, the fact that the early epic, as it has come down to us, appears in prose instead of poetry may be due, at least in part, to the disappearance of native metrical forms before the fifth century. It may be that the prose epics originated in paraphrases of early poems such as we find, for instance, in the Völsunga Saga, which is a paraphrase of older poems dealing with the story of Sigurthr. Or the change may have been more automatic, the outcome of a process of metrical dissolution similar to that of which the beginnings may be seen in certain Anglo-Saxon and German poems. Such metrical dissolution would be favoured,

${ }^{1}$ See Kuno Meyer: Learning in Irelant in the Fifth Century (Dublin, 1913). 
if not necessitated, by the extensive phonetic changes which took place in Ireland in the fifth century. But into this question it is not necessary to enter here. It is sufficient to point out that Irish Saga literature, according to all appearances, began in the heroic epic, a form which in all other literatures, including Norse, originated in poetry.

The preservation of poetry, narrative or other, by oral tradition is a common enough phenomenon among many peoples, but the traditional prose narrative, except in such primitive forms as folk-tales, is very rare. Since we find it both in Ireland and Iceland-and apparently in no other European countries-and since we have found so many other connections between these two countries, the theory that the Icelandic Saga owes its origin, however indirectly, to the Irish Saga, seems to deserve more serious consideration from scholars than it has yet received. 


\section{BIBLIOGRAPHY.}

I.

Annals of Clonmacnois, ed. by Rev. D. J. Murphy. Dublin, 1896. Annals of the Kingdom of Ireland by the Four Masters (Vols. I. and II.), ed. by J. O'Donovan, Dublin, 1856 .

Three Fragments of Irish Amals, ed. by J. O'Donovan. Dublin, 1860 .

Annals of Tigernach, ed. by Whitley Stokes (Revue Celtique, XVI.; XVII.). Paris, I895.

Annals of Ulster (Vol. I.), ed. by W. M. Hennessy. Dublin, 1887. Black Book of Limerick, ed. by J. MacCaffrey. Dublin, 1907.

Book of Rights (Leabhar na gceart), ed. by J. O'Donovan. Dublin, 1847 .

Brennu-Njálssaga, ed. by Finnur Jónsson. Halle a S., 1908.

The Story of Burnt Njal, translated by Sir G. W. Dasent. London, I86I.

(Several subsequent editions.)

Caithriem Cellachain Caisil: The Victorious Career of Cellachan of Cashel, ed. by A. Bugge. Christiania, 1905.

Chronicon Scotorum, ed. by W. M. Hennessy. London, 1866.

Cogadh Gaedheal re Gallaibh (The War of the Gaedhil with the Gaill) ed. by J. H. Todd. London, I867.

Eyrbyggja Saga, ed. by H. Gering. Halle a S., I 897 .

(English translation by E. Magnússon and William Morris, Irondon, I 892).

Fornaldar Sögur, ed. by C. C. Rafn. Copenhagen, 1829-30.

Fornmanna Sögur. Copenhagen, I825-1837.

Fostbroethra Saga, ed. by V. Ásmundarson, Reykjavík, 1899.

Gunnlaugs Saga Ormstungu, ed. by V. Ásmundarson. Reykjavỉk, I9II.

Heimskringla, ed. by C. R. Unger. Christiania, 1868. Kormaks Saga, ed. by V. Ásmundarson. Reykjavik, 1893. Landnámabók, ed. by V. Ásmundarson. Reykjavik, 1909.

(English translation by Rev. T. Ellwood. Kendal, 1898.) 
On the Fomorians and the Norsemen (Duald Mac Firbis), ed. by A. Bugge. Christiania, 1905.

Origines Islandicae, ed. by G. Vigfusson and F. York Powell. Oxford, 1905.

Orkneyinga Saga, ed. and tr. by J. Anderson. Edinburgh, 1873 . Also tr. by Sir G. W. Dasent for the Rolls Series. London, 1894. Sturlunga Saga, ed. by G. Vigfusson. Oxford, 1878 .

Thorsteins Saga Sithu-Hallssonar, ed. by V. Ásmundarson. Reykjavik, 1902.

Two of the Saxon Chronicles (Parallel), 2 Vols., ed. by Earle and Plummer. Oxford, 1892 and 1899.

II.

Bugge, A. ... ... Contributions to the History of the Norsemen in Ireland. Christiania, I900.

Vesterlandenes Indflydelse paa Nordboernes .........i Vikingetiden. Christiania, 1905.

Collingwood, W. G. ... Scandinavian Britain. London, 1908.

Craigie, W. A. ... The Icelandic Sagas. Cambridge, I9r3.

Du Chaillu, P. B. ... The Viking Age, 2 Vols. London, I889.

Henderson, G. ... The Norse Influence on Celtic Scotland. Glasgow, I9ro.

Jónsson, F. ... ... Old Norske Litteraturs Historie, also (abridged). Copenhagen, 1907.

Joyce, P. W. $\quad$... A Social History of Ancient Iraland, 2 Vols. Dublin, I9r3.

Keary, C. F. ... The Vikings in Western Christendom. London, r89I.

Kermode, P. M. C. Manx Crosses. London, I9'07.

Marstrander, C. ... Bidrag til det Norske Sprogs Historis i Irland. Christiania, I9I2.

Mawer, A. ... ... The Vikings. Cambridge, I9r3.

Mogk, E. ... ... Geschichte der Norwegisch-Isländischen Literatur. Strassburg, 1904.

O'Curry, E. ... ... On the Manners and Customs of the Ancient Irish (ed. by W. K. Sullivan). London, 1873.

... Lectures on the Manuscript Materials of Ancient Irisk History. Dublin, I86r. 
Steenstrup, J. C. H. R. Normannerne (Vols. II. and III.). Copenhagen, r876-82.

Stokes, G. T. ... Ireland and the Celtic Church (revised by H. J. I, awlor). Loudon, 1907 .

Vogt, L. J. ... ... Dublin som Norsk By. Christiania, 1896.

The Whole Works of Sir James Ware concerning Ireland, 2 Vols. (translated and continued by W. Harris). Dublin, 1764.

Worsaae, J. J. A. ... Minder om de Danske og Nordmaendene $i$ England, Skotland og Irland. Copenhagen, $185 \mathrm{I}$.

(English translation: An Account of the Danes and Norwegians in England, Scotland and Ireland. London, 1852.)

Zimmer, H. ... ... The Celtic Church in Britain and Ireland, (translated by A. Meyer). I,ondon, I902.

Reference has also been made to the following articles:Bugge, A. $\quad \ldots \quad \ldots$ Nordisk Sprog og Nordisk Nationalitet $i$ Irland (Aarboger for Nordisk Oldkyndighed og Historie, 1900, pp. 279-332).

Craigie, W. A. Bidrag Bidet Sidste Afsnit af Nordboernes Historie $i$ Irland ibid., 1904. pp. 248-315.

Curtis, E. ... $\quad \ldots \quad$ The English and the Ostmen in Ireland
(English Historical Review, XXIII., p.
209 ff.) Oldnordiske Ord $i$ de Gaeliske Sprog (Archiv for Nordisk Filologi. 1894.)

Hull, E. $\quad \ldots \quad \ldots$ Irish Episodes in Icelandic Literature (Saga Book of the Viking Club. January, r903.)

... The Gael and the Gall: Notes on the Social Condition of Ireland during the Norse Period. (Ibid. April, rgo8.)

Mawer, A. ... ... The Scandinavian Kingdom of Northumbria. Ibid. January, I9r.

Stokes, W. ... ... A few Parallels between the Old Norse and the Irish Literatures and Traditions (Arkiv fôr Nordisk Filologi. 1885.)

Zimmer, H. ... ... Ueber die frühesten Berührungen der Iren mit den Nordgermanen. (Sitzungsberichte der Kgl. Preussichen Akademie der Wissenschaften, Bd. I., pp. 279-3 I 7. Berlin, 1891.) 


\section{N D E X.}

Aedh Finnliath, 10, 15.

Albann, brother of Ivarr the Boneless, 4.

Albdann, son of Gothfrith, $22 n$.

Altar-ring, 53, 54.

aonach, $30,67$.

Armagh, 21-22, 48, 52, 55.

Art, Scandinavian influence on Irish, 20.

Authr, wife of Olaf the White, 15, 48, 72; wife of Turgéis, 47.

Brian Borumha, 7-8, 29, 37-38.

Brunanburh, battle of, 6,24 .

Burial mounds, 12.

Canterbury, 55-56.

Carlingford Lough, battle of, 3, 13, 50-51.

Cearbhall, king of Ossory, 13-15, 50, 72, 73.

Cellachan, king of Cashel, 26, 36-37.

Chester, siege of, 12.

Clontarf, battle of, 8-9, 54 .

Colla, 25.

Cork, 27, 30.

Danes, 2-4, 12, 13, 24-27, 50-1.

dóm-hringr, 53-4.

Dublin, fortress built at, 2 ; seat of Scandinavian kings, 3, 5-7 ;

Vikings driven from, 5 ; coins minted in, 19 ; early history, $21-3$; as a trade centre, 30-1, 70-1.

epscop, 29.

Erríc Blood-axe, 7.

Fingal, 8.

Finn Gaill, $3 n$. 
Gaill-Gaedhil, 10-11, 38.

gelt, 44.

Gleann Máma, battle of, 8, 30, 54 .

Glûniarainn, 17-8.

Gnimcinnsiolla, 27.

Gormflaith, wife of Brian Borumlia, 8, 17, 54; wife of Niall Glûndubh, 68.

Gothfrith, king of Dublin, 6, 24.

Heathenism, 47-8, 50-4.

Hebrides, 17, 25, 36, 41 n., 48-9.

Iceland, $13 n ., 8,57-8,66,71$.

Ivarr the boneless, 3-4, 11, 48; king of Limerick, 7, 24, $70 \mathrm{n}$., king of Waterford, 18.

Ketill Flatnose, 48-9 ; Ketill " the foolish," 49, 72.

Kilmashogue, battle of, 5 .

lagmainn, 41.

Lambey, 1.

Limerick, 7, 9, 23-5, 30-1.

longphort, 2, 34, 35.

Mac Iiag, 70

Maelsechnaill I (Malachy), 2, 11; Maelsechnafll II, 7-8, 17, 70. Melkorka, 16, 31, 73.

Morann, son of the king of Lewis, 25.

Muirchertach of the Leather Cloaks, 6, 16-7.

Niall Glûndubh, 5, 68.

Norsemen, passim.

Northumbria, 5-7.

Norway, 4, 16, 32, 59.

Olaf Cuaran (Sihtricsson), 6-7, 17, 34, 40, 53, 71 ; Godfreyson, 6,26 ; Olaf the White, 3-4, 11-2, 15, 48 ; Trygr asson, 13-4. Ostmen, 9, 26.

Ota, wife of Turgéis, 2, 47. 
Place-names, Scandinavian influence on Irish, 27-8; Irish influence on Icelandic, 45-6. prime-signing, 75.

Raghnall, grandson of Ivarr, 5,25 .

Runic inscriptions, $27 n$., 51-2.

Settlers in Iceland, $13 n, 71,72$.

Sihtric Silken Beard, 8, 19, 34, 54-5, 70.

Sigurd, earl of Orkney, 8, $15 n$.

Slave traffic, 32-3, 72-3.

Story-telling in Iceland, 58-64; in Ireland, 67-9.

Sulcoit, battle of, 7 .

Tengmouth, $22 n$.

thing, 22, 61, 67.

Turgeis, 1-2, 21, 23.

Waterford, 5, 9, 23, 25-6, 30 .

Wexford, 22, 23, 30 .

völva, 47.

York, 5, 6, 23. 


$$
\text { - }
$$




\section{UCSE LIBRARY $x-22478$}

SOUTHERN REGIONAL LIBRARY FACILITY

405 Hilgard Avenue, Los Angeles, CA 90024-1388

Return this material to the library from which it was borrowed.

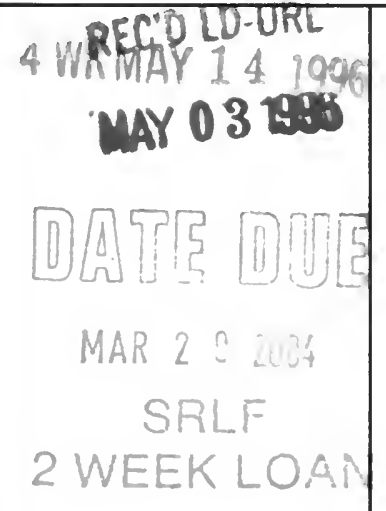




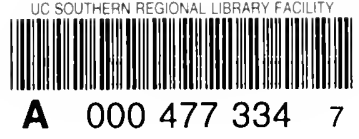


